\title{
Selective Enrichment and Identification of Azide-tagged Cross-Linked Peptides Using Chemical Ligation and Mass Spectrometry
}

\author{
Danielle Vellucci, ${ }^{\mathrm{a}}$ Athit Kao, ${ }^{\mathrm{b}}$ Robyn M. Kaake, ${ }^{\mathrm{b}}$ Scott D. Rychnovsky, ${ }^{\mathrm{a}}$ \\ and Lan Huang ${ }^{\mathrm{b}}$ \\ a Department of Chemistry, University of California, Irvine, California, USA \\ ${ }^{\mathrm{b}}$ Departments of Physiology and Biophysics and Developmental and Cell Biology, University of California, \\ Irvine, California, USA
}

\begin{abstract}
Protein-protein interaction is one of the key regulatory mechanisms for controlling protein function in various cellular processes. Chemical cross-linking coupled with mass spectrometry has proven to be a powerful method not only for mapping protein-protein interactions of all natures, including weak and transient ones, but also for determining their interaction interfaces. One critical challenge remaining in this approach is how to effectively isolate and identify cross-linked products from a complex peptide mixture. In this work, we have developed a novel strategy using conjugation chemistry for selective enrichment of cross-linked products. An azide-tagged cross-linker along with two biotinylated conjugation reagents were designed and synthesized. Cross-linking of model peptides and cytochrome $c$ as well as enrichment of the resulting cross-linked peptides has been assessed. Selective conjugation of azide-tagged cross-linked peptides has been demonstrated using two strategies: copper catalyzed cycloaddition and Staudinger ligation. While both methods are effective, Staudinger ligation is better suited for enriching the cross-linked peptides since there are fewer issues with sample handling. LC MS ${ }^{n}$ analysis coupled with database searching using the Protein Prospector software package allowed identification of 58 cytochrome $c$ cross-linked peptides after enrichment and affinity purification. The new enrichment strategy developed in this work provides useful tools for facilitating identification of cross-linked peptides in a peptide mixture by MS, thus presenting a step forward in future studies of protein-protein interactions of protein complexes by cross-linking and mass spectrometry. (J Am Soc Mass Spectrom 2010, 21, 1432-1445) ( 2010 American Society for Mass Spectrometry
\end{abstract}

$\mathrm{P}$ roteins form stable and/or dynamic multisubunit protein complexes under different physiologic conditions to maintain cell viability and normal cell homeostasis. A thorough understanding of protein interactions and structures of protein complexes is fundamental to the understanding of protein function and regulation. Chemical cross-linking coupled with mass spectrometry (MS) is a powerful method that can be used to study protein-protein interactions [1-6]. The unique capability of chemical cross-linking to stabilize protein interactions through covalent bond formation allows not only the structural elucidation [7-17], but also the detection of stable, weak, and/or transient protein-protein interactions in native cells or tissues [18-25].

In addition to capturing protein interacting partners, many studies have shown that chemical cross-linking can yield low-resolution structural information about the constraints within a molecule [2-4]. Traditional methods such as NMR analysis and X-ray crystallography can yield detailed information on protein structure, however NMR

Address reprint requests to Dr. L. Huang, Medical Science I, D233, Department of Physiology and Biophysics, Department of Developmental and Cell Biology, University of California, Irvine, CA 92697-4560, USA. E-mail: lanhuang@uci.edu spectroscopy requires large quantities of pure protein in a specific solvent, and X-ray crystallography is often limited by the crystallization process. The combination of chemical cross-linking, enzymatic digestion, and subsequent mass spectrometric analysis for the elucidation of threedimensional protein structures offers distinct advantages over these traditional methods due to its speed, sensitivity, and versatility [2-4]. This strategy has been successfully employed for unraveling protein complex topology and protein-protein interacting interfaces [7-17, 26].

Due to the inherent complexity in cross-linking reactions and the abundance of non-cross-linked peptides, detection of cross-linked peptides in a complex mixture is quite challenging $[2,4]$. The digested mixture of crosslinked protein complexes typically contains four types of peptides: (1) unmodified peptides of the complex components, (2) dead end modified peptides, (3) intramolecular (inter-linked and intra-linked) cross-linking products between peptides originated from one protein, and (4) intermolecular cross-linking products (inter-linked) between peptides from different proteins $[3,8]$. To facilitate the identification process, various methods using biotinylated [27-31], isotope-labeled [32-34], fluorescently labeled [35, 36], or mass-tag labeled cross-linking reagents 
$[28,37]$ have been reported. Among them, biotinylated cross-linkers are advantageous due to their specificity and efficiency. However, these linkers have the drawback of being bulky and therefore not very effective or ideal for in vivo protein cross-linking [4, 38]. Recently, new strategies have also been developed based on click chemistry with chemical conjugation of azide and alkyne groups using alkyne-tagged [39] or azide tagged [40,41] cross-linkers. Applications using click chemistry for enrichment of other types of biomolecules have also been reported [42-49]. The marked advantage of this approach is the complete orthogonality to functional groups in normal biomolecules since azides and alkynes are not present in peptides, proteins, nucleic acids, or polysaccharides, and are very rare in all other biological materials and natural products. With the absence of significant competing reactions [43], click chemistry shows great promise for protein cross-linking studies.

Although both alkyne-tagged [39] and azide-tagged cross-linkers [41] can be used for the same purpose, azide-tagged reagents have some advantages that would be preferred. Azides present a high chemical stability under physiologic conditions and unlike alkynes, their reactivity enables several types of mild and selective organic transformations, including $\mathrm{Cu}(\mathrm{I})$-catalyzed [3+2] cycloaddition [42, 50], strain-promoted [3+2]-cycloaddition $[49,51,52]$, and Staudinger ligation [53-55]. The Staudinger ligation has been widely used in biological applications, especially for selective enrichment of chemically modified peptides [56-61], but its applicability in the study of cross-linked peptides has not been evaluated. Due to complications in sample handling using copper-catalyzed click chemistry and challenges in synthesizing strained alkynes, the alternative strategy using Staudinger ligation may be advantageous for isolation of cross-linked peptides. In this work, we have explored azide-based conjugation chemistry using Staudinger ligation and developed a new enrichment strategy for cross-linked peptides using a newly designed azide-tagged cross-linker and biotin-phosphine. These new reagents not only allow efficient cross-linking of model peptides and cytochrome $c$ and subsequent enrichment of cross-linked peptides, but also provide diagnostic ions in MS/MS analysis to facilitate MS identification of cross-linked peptides with high confidence. In combination with various software tools (i.e., Batch-tag, MS-bridge, MS-product and Search compare) in Protein Prospector [62], LC MS/MS analyses allowed identification of 58 enriched cytochrome $c$ cross-linked peptides.

\section{Materials and Methods}

\section{Materials and Reagents}

All general chemicals for buffers were purchased from Fisher Scientific, now owned by ThermoFisher Scientific, Waltham, MA, USA or VWR International, West Chester, PA, USA. Bovine heart cytochrome $c$ (98\% purity) was purchased from Sigma-Aldrich, St. Louis, MI, USA. Ac- myelin peptide (Ac-ASQKRPSQRHG, 92.7\% purity) was purchased from American Peptide (Sunnyvale, CA) and Ac-IR7 peptide (Ac-IEAEKGR, 98.1\% purity) was synthesized by GL Biochem (Shanghai, China).

\section{Synthesis and Characterization of Azide-DSG, Biotin-Alkyne, and Biotin-Phosphine}

The synthesis schemes for azide-DSG (S-5) (spacer length $7.7 \AA$ ), biotin-alkyne (S-11), and biotin-phosphine (S-17) are displayed in Figure 1. As shown, azide-DSG was synthesized from commercially available dimethyl 1,3acetonedicaboxylate (S-1) in four steps. Biotin-alkyne was synthesized from S-6 in five steps. Biotin-phosphine was synthesized from S-12 in three steps based on Bertozzi's protocols [53, 63]. The details in synthesis and chemical characterization of each product have been summarized in Supplemental methods, which can be found in the electronic version of this article.

\section{Cross-Linking of Synthetic Peptides with Azide-DSG}

A solution of tryptic-like synthetic peptides Ac-myelin or Ac-IR7 $(0.31 \mu \mathrm{mol})$ in DMF $(400 \mu \mathrm{L})$ was mixed with $20 \mu \mathrm{l} 8 \mathrm{mmol} / \mathrm{L}$ azide-DSG cross-linker in DMF, and the reaction mixture was treated with $20 \mu \mathrm{L} 8 \mathrm{mmol} / \mathrm{L}$ diisopropylethylamine in DMF. The reaction mixture was stirred for $16 \mathrm{~h}$ at ambient temperature. The solution was then dried by SpeedVac and resuspended in PBS buffer or $20 \%$ ACN.

\section{Cross-Linking of Cytochrome $c$ with Azide-DSG}

Two hundred $\mu \mathrm{M}$ bovine cytochrome $c$ in 1X PBS $(\mathrm{pH}$ 7.5) was reacted with azide-DSG in DMSO at 20:1 (linker:protein) molar ratio and incubated at room temperature for $1 \mathrm{~h}$ with agitation. After quenching with glycine, it was then digested with $1 \%$ trypsin (wt/wt) overnight at $37^{\circ} \mathrm{C}$ before enrichment.

\section{Enrichment of Azide-Tagged Cross-Linked Peptides Using Copper Catalyzed Click Chemistry}

A solution of azide-DSG cross-linked Ac-myelin peptide $\left(20 \mu \mathrm{L}, 2.6 \times 10^{-8} \mathrm{~mol}\right)$ in PBS buffer was treated with $20 \mu \mathrm{L}$ of a $13 \mathrm{mM}$ solution of biotin-alkyne in DMSO. Subsequently, $40 \mu \mathrm{L}$ of $6.5 \mathrm{mM} \mathrm{CuSO} \cdot 5 \mathrm{H}_{2} \mathrm{O}, 4 \mu \mathrm{L}$ of 193 mM sodium ascorbate, and $8 \mu \mathrm{L}$ of $6.3 \mathrm{mM}$ TBTA solution were added [64]. The reaction mixture was gently stirred for $18 \mathrm{~h}$. The solution was then desalted by a C18 ZipTip (Varian, Palo Alto, CA, USA), dried by SpeedVac, and resuspended in $1.2 \mathrm{~mL}$ of $4 \% \mathrm{ACN} / 0.1 \%$ formic acid. Following desalting, $5 \mu \mathrm{L}$ of the mixture was incubated with $400 \mu \mathrm{L}$ of Dynabeads M-280 streptavidin (Invitrogen, Carlsbad, CA, USA). After $30 \mathrm{~min}$ incubation, the beads were washed with PBS buffer and 20\% ACN. Peptides were eluted from the beads with $90 \%$ TFA. The TFA 
(a)
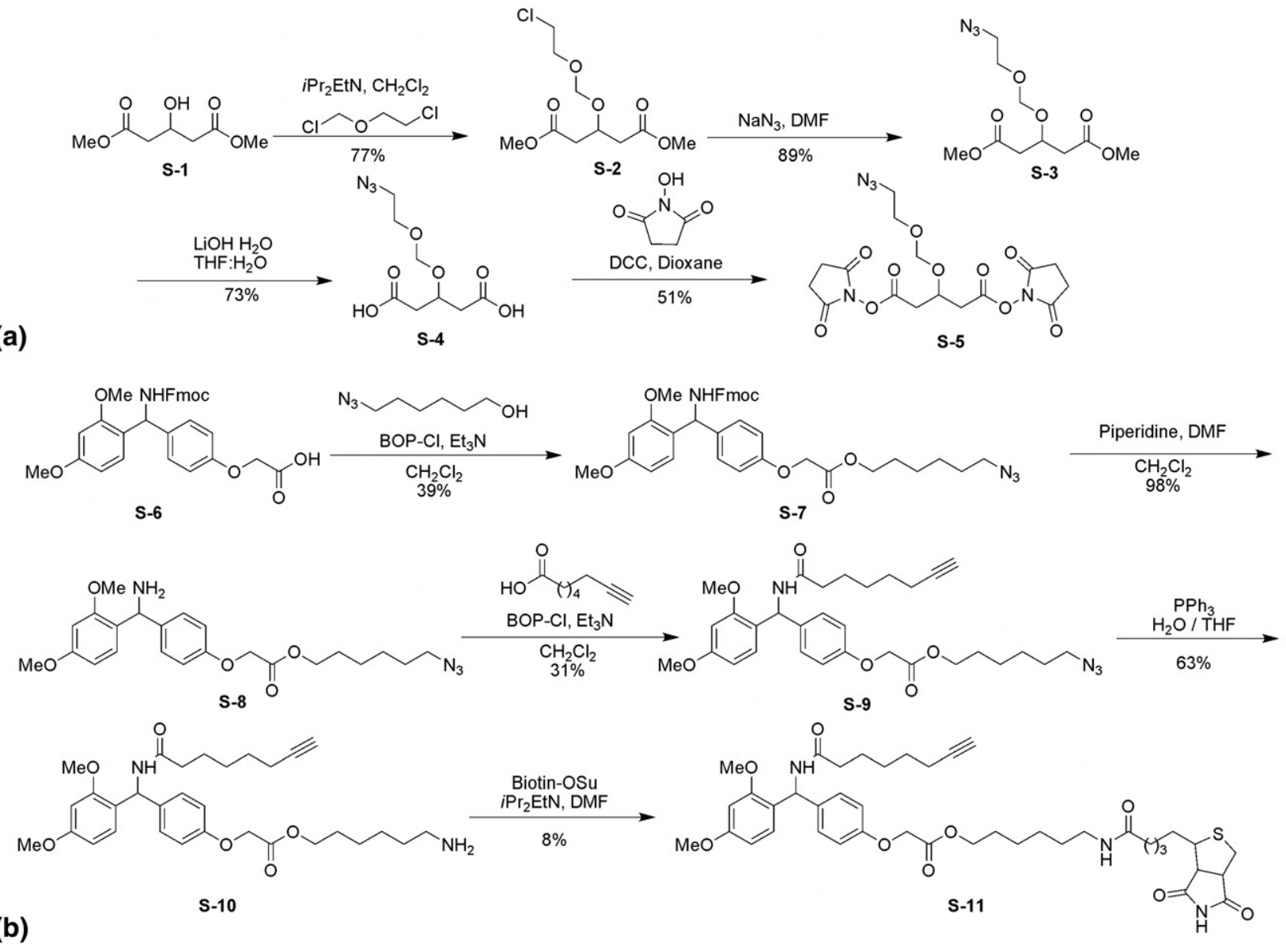

(b)
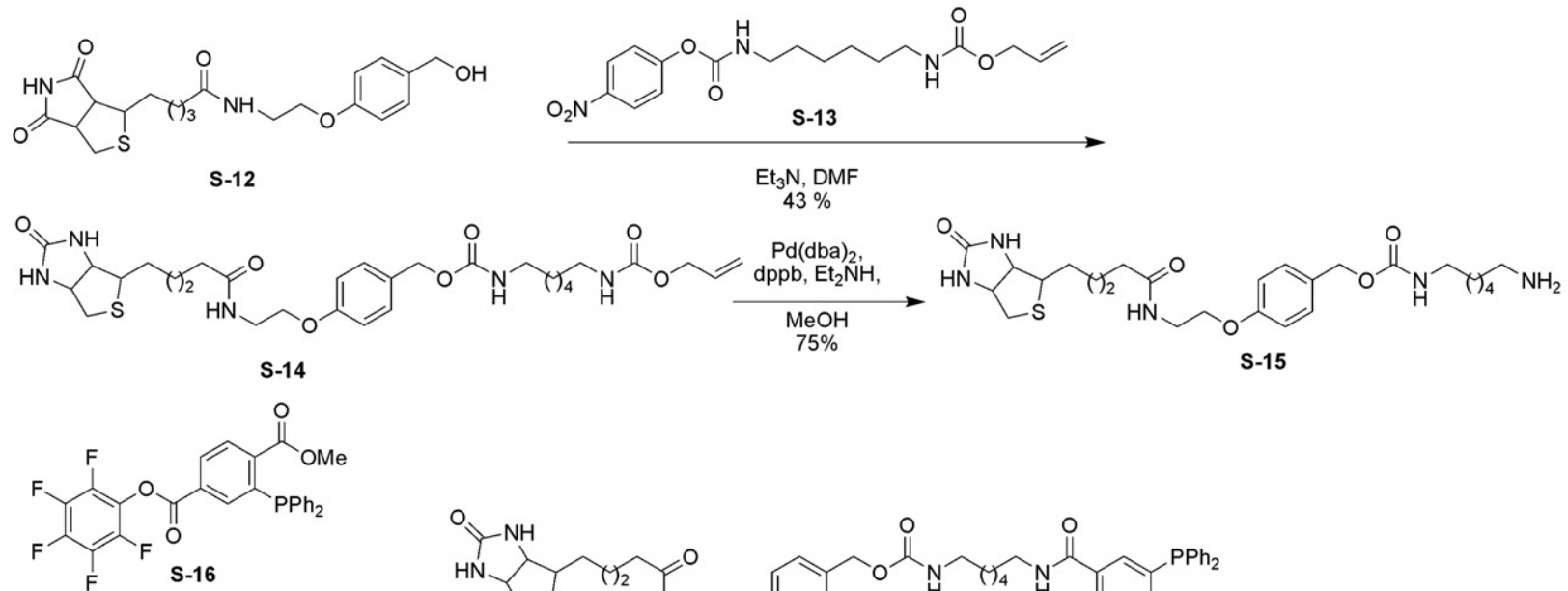

$\mathrm{PPr}_{2} \mathrm{EtN}, \mathrm{DMF}$

(c)

$39 \%$

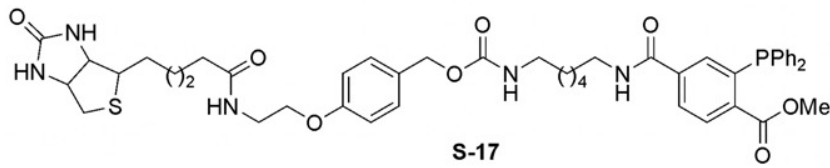

Figure 1. Synthetic schemes of (a) azide-DSG (S-5); (b) biotin-alkyne (S-11); (c) biotin-phosphine (S-17).

solution was dried by SpeedVac and resuspended in $4 \%$ $\mathrm{ACN} / 0.1 \%$ formic acid for analysis.

\section{Enrichment of Azide-Tagged Cross-Linked Peptides Using Staudinger Ligation}

Staudinger ligation was performed with a similar procedure as described [53]. Briefly, $10 \mu \mathrm{L}$ of azide-DSG cross-linked Ac-myelin peptide $\left(7.73 \times 10^{-9} \mathrm{~mol}\right)$ was treated with $7 \mu \mathrm{L}$ of a $25 \mathrm{mM}$ stock solution of biotinphosphine (S-17 in Figure 1) in DMSO. The reaction mixture was heated to $60^{\circ} \mathrm{C}$. After $16 \mathrm{~h}, 1.5 \mu \mathrm{L}$ of the reaction mixture was incubated with $200 \mu \mathrm{L}$ of Dynabeads M-280 streptavidin (Invitrogen). After $30 \mathrm{~min}$, the beads were washed with $200 \mu \mathrm{L}$ of $20 \%$ ACN, $200 \mu \mathrm{L}$ of PBS buffer, and $200 \mu \mathrm{L}$ of $25 \%$ isopropanol. The 
peptides were then eluted with $85 \%$ TFA. The TFA solution was dried by SpeedVac and the sample was resuspended in 4\% ACN/0.1\% formic acid for LC MS analysis.

\section{LC $M S^{n}$ Analysis}

LC MS ${ }^{n}$ analysis of cross-linked peptides was carried out using an LTQ-Orbitrap XL MS (Thermo Scientific, San Jose, CA, USA) coupled with an Eksigent NanoLC system (Eksigent, Dublin, CA, USA). The LC analysis was performed using a capillary column $(100 \mu \mathrm{m}$ i.d. $\times 150 \mathrm{~mm}$ long) packed with C18 resins (GL Sciences, Torrance, CA, USA) and the peptides were eluted using a linear gradient of $2 \%-40 \%$ B in 35 min; (Solvent A: $100 \% \mathrm{H}_{2} \mathrm{O} / 0.1 \%$ formic acid; Solvent B: $100 \% \mathrm{ACN} /$ $0.1 \%$ formic acid). For LC MS/MS analysis, a cycle of one full FT MS scan mass spectrum (350-1800 m/z, resolution of 60,000 at $\mathrm{m} / \mathrm{z} 400$ ) was followed by 10 data-dependent MS/MS acquired in the linear ion trap with normalized collision energy (setting of 35\%). Target ions selected for MS/MS were dynamically excluded for $30 \mathrm{~s}$. For LC MS ${ }^{3}$ analysis, one full FT MS scan was followed by two cycles of one MS/MS scan and three $\mathrm{MS}^{3}$ scans acquired in the linear ion trap. $\mathrm{MS}^{3}$ scan was operated in data-dependent mode to allow sequencing the top three most abundant fragment ions observed in a MS/MS spectrum with exclusion of 447.2, 508.2, and 520.2 ions, which are diagnostic ions of cross-linked peptides due to fragmentation in the conjugated cross-linker region in MS/MS.

\section{Identification of Cross-Linked Peptides by Database Searching}

Monoisotopic masses of parent ions and corresponding fragment ions, parent ion charge states and ion intensities from LC MS/MS spectra were extracted using in-house software based on Raw_Extract script from Xcalibur ver, 2.4 (Thermo Scientific). Database searching was performed with a developmental version of Protein Prospector (ver. 5.3.2., http://proteinprospector. ucsf.edu) using its software suite, i.e., Batch-tag, MS-bridge, MS-product, MS-tag and Search Compare, similarly as described [62]. It has been shown that Batch-tag with mass modification search can be applied for identifying cross-linked peptides [62]. Therefore, the MS/MS data were first searched using Batch-tag with mass modification against bovine cytochrome $c$ sequence (SwissProt accession no. P62894). Mass modification up to $4000 \mathrm{Da}$ was set on uncleaved lysine residues and protein free $\mathrm{N}$-terminus. The mass accuracy for parent ions and fragment ions were set as \pm 0.25 and $0.8 \mathrm{Da}$, respectively. The other search parameters included trypsin as the enzyme, two maximum missed cleavages, and three maximum variable modifications. Variable modifications chosen were protein N-terminal acetylation, methionine oxidation, and N-terminal con- version of glutamine to pyroglutamic acid. For all of the ions being sequenced in MS/MS, their parent monoisotopic masses and charges were extracted from Search Compare and submitted to MS-bridge program to identify putative cross-linked peptides by mass fitting against theoretical masses of cross-linked cytochrome $c$ peptides with the given cross-linker. The parent mass error for MS-bridge search was set as $\pm 20 \mathrm{ppm}$ and only one bridge was allowed in the cross-linked peptides. All of the three types of cross-linked peptides [8], i.e., inter-linked (type 2), intra-linked (type 1), and dead-end modified (type 0) peptides, can be computed and matched in MS-bridge. MS-tag was used to identify the additional peptide sequence in the inter-linked peptides, and MS-product was applied to validate the identified sequences. Due to difficulties in the analysis of the complex fragmentation of cross-linked peptides by automated database searching, $\mathrm{MS}^{3}$ spectra interpretation was performed manually.

\section{Results and Discussion}

\section{Selective Isolation of Cross-Linked Peptides}

In this work, a new cross-linking and enrichment strategy was developed to enable effective isolation of cross-linked peptides from a complex mixture. Figure 2 shows the overview of the cross-linking reaction and enrichment protocols. A novel azide-tagged NHS esterbased cross-linker (i.e., azide-DSG) was designed and synthesized (S-5 in Figure 1a) such that the azide tag could be used as a chemical handle to allow selective isolation of azide-tagged cross-linked peptides using azide-based conjugation chemistry including azidealkyne cycloaddition and Staudinger ligation chemistry [42, 49-55]. Azide-DSG was chosen for this work due to its desirable water solubility, spacer length, membrane permeability, expected stability, and ease of synthesis. To determine the chemistry best suited for enrichment of cross-linked peptides from complex mixtures, we have designed and synthesized two new biotinylated conjugation reagents (S-11 and S-17 in Figure 1a and c) for enrichment strategies based on either copper catalyzed click chemistry (Figure 2c) or Staudinger ligation (Figure 2d), and their effectiveness has been evaluated using model peptides as described below.

1. Enrichment of azide-tagged cross-linked peptides using copper catalyzed click chemistry. Click chemistry-based strategy (Figure 2c) was first evaluated using a model peptide Ac-myelin. Cross-linking of Ac-myelin was carried out in organic solvents with about equal molar amount of azide-DSG and the resulting products were analyzed by LC MS/MS. The crosslinking reaction appeared to be highly effective as no unmodified peptide was detected in MS spectra after the reaction. Only two types of cross-linking products, i.e., inter-linked (type 2) and dead-end (type 0$)$ modified peptides, were detected with the 


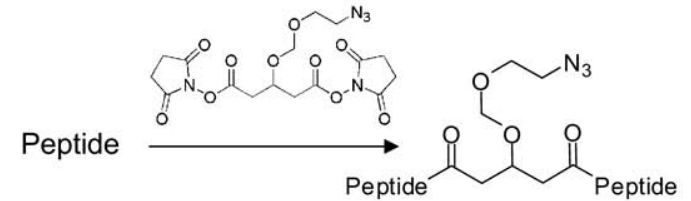

(a)

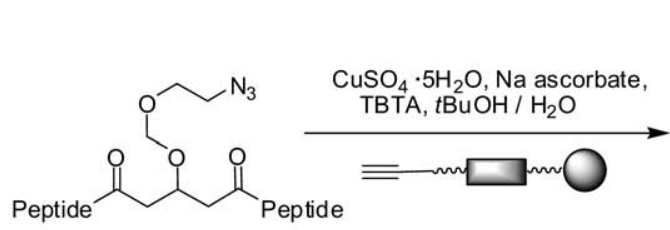

(c)

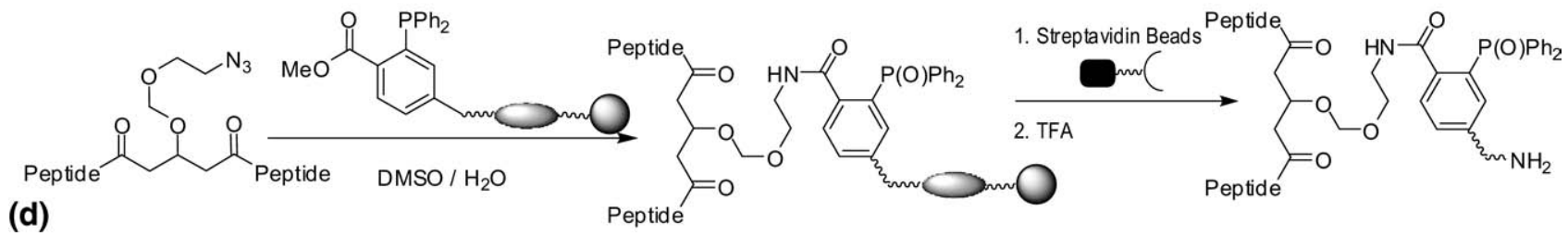

Figure 2. Schematic overview of general cross-linking and enrichment strategies. (a) Cross-linking of a peptide using azide-DSG; (b) cartoon structures of biotin-alkyne and biotin-phosphine (see detailed structures in Figure 1); Enrichment strategies based on (c) copper catalyzed click chemistry; (d) Staudinger ligation.

inter-linked product as the major product under our experimental conditions. This can be attributed to $\mathrm{N}$-acetylation of Ac-myelin, one lysine residue in the sequence, and the limited hydrolysis of the cross-linker. The structural illustration and MS spectra of the azide-tagged cross-linked products of Ac-myelin are displayed in Figure 3a-c. A series of ions $\left([\mathrm{M}+6 \mathrm{H}]^{6+}\right.$ 467.07, $[\mathrm{M}+5 \mathrm{H}]^{5+}$ 560.29, $[\mathrm{M}+$ $\left.4 \mathrm{H}]^{4+} 700.11\right)$ were detected as the Ac-myelin homodimer and a triply charged ion $\left([\mathrm{M}+3 \mathrm{H}]^{3+}\right.$ 508.26) was measured as the dead-end modified Ac-myelin. The mass addition to the cross-linked peptides was $211 \mathrm{Da}$ for the cross-link (inter- or intra-link) and $229 \mathrm{Da}$ for the dead-end modification. To isolate the cross-linked peptides, the azidetagged cross-linked Ac-myelin products were subjected to conjugation with a biotin-alkyne (S-11) (Figure 1b). An acid cleavable site was incorporated into the new biotin-alkyne to allow subsequent elution after streptavidin-biotin binding during affinity purification of enriched cross-linked peptides. Upon cycloaddition, the conjugated products containing a triazole was formed for both inter-linked and dead-end modified Ac-myelin peptides and measured by MS analysis as displayed in Figure $3 \mathrm{~d}-\mathrm{f}$. The azide-alkyne cycloaddition reaction was very efficient since no detectable non-conjugated cross-linked peptides were detected. After conjugation, the cycloaddition products were isolated by binding to magnetic streptavidin beads followed by
TFA cleavage (Figure 2c). The structural illustration and MS spectra of final Ac-myelin cross-linked products are shown in Figure $3 \mathrm{~g}-\mathrm{i}$. A series of ions $\left([\mathrm{M}+6 \mathrm{H}]^{6+} 490.28,[\mathrm{M}+5 \mathrm{H}]^{5+} 588.13,[\mathrm{M}+4 \mathrm{H}]^{4+}\right.$ 734.92) were observed for inter-linked Ac-myelin, and a triply charged ion $\left(\mathrm{MH}_{3}{ }^{3+} 554.65\right)$ was detected for the dead-end product. Although isolation of azide-tagged Ac-myelin cross-linked products using copper catalyzed click chemistry was successful, we found that addition of $\mathrm{CuSO}_{4}$ and sodium ascorbate to the reaction mixture often caused peptide precipitation, leading to problems in sample handling and sample losses. In addition, it has been noted that copper (I) may induce peptide oxidation and thus hamper identification of the cross-linked peptides by MS [41].

2. Enrichment of azide tagged cross-linked peptides using Staudinger ligation. To avoid the problems associated with copper catalyzed click reaction, we have investigated a strategy based on Staudinger ligation using a biotin-phosphine with an acid cleavage site (S-17) (Figure 1c). The azide-DSG cross-linked Acmyelin products were then subjected to Staudinger ligation and the resulting conjugates were affinity purified by binding to magnetic streptavidin beads followed by TFA cleavage. The products at each step were monitored by LC MS/MS. Optimization of reaction temperature was carried out by comparing LC MS signal intensity of the cross-linked and non-cross-linked Ac-myelin before and after the 
(a)

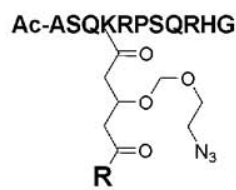

\section{$R=$ AC-ASQKRPSQRHG} (inter-link)

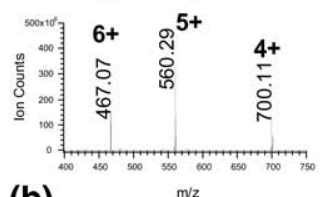

(b)

$\mathrm{R}=\mathrm{OH}$

(Dead-end)

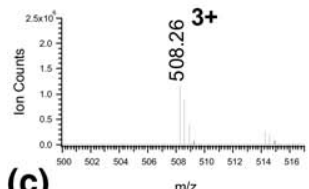

(c)

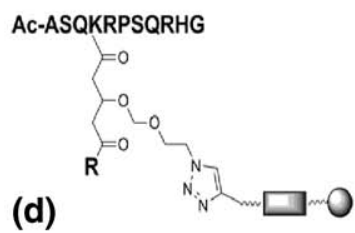

$R=A C-A S Q K R P S Q R H G$ (inter-link)

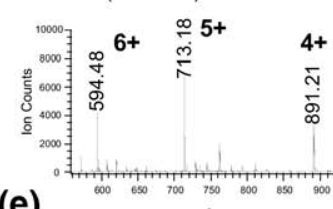

(e)

$\mathrm{R}=\mathrm{OH}$

(Dead-end)

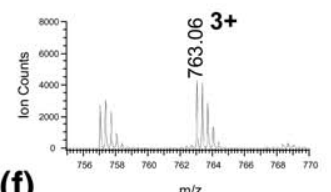

(f)
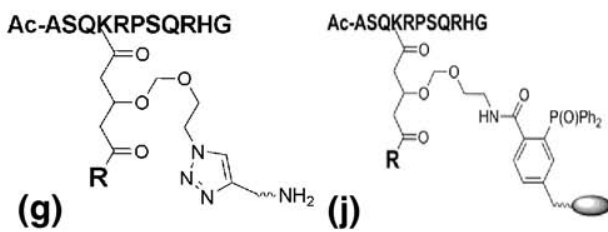

\section{$R=$ Ac-ASQKRPSQRHG}

(inter-link)

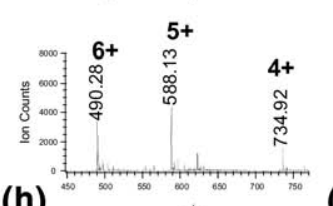

(h)

$\mathrm{R}=\mathrm{OH}$

(Dead-end)

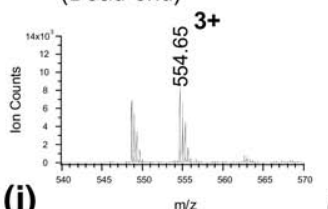

(i) (inter-link)

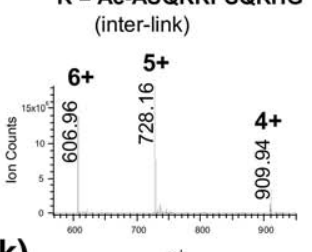

(k)

$\mathbf{R}=\mathbf{O H}$

(Dead-end)

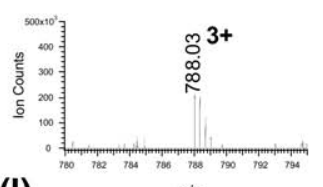

(m)

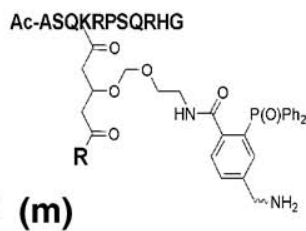

$\mathbf{R}=\mathrm{Ac}-\mathrm{ASQKRPSQRHG}$ (inter-link)

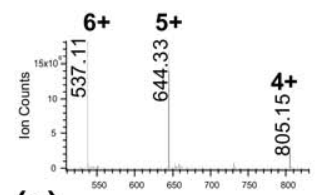

(n)

$\mathbf{R}=\mathbf{O H}$ (Dead-end)

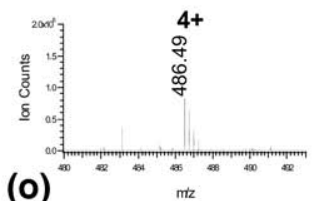

Figure 3. Enrichment of azide-DSG cross-linked Ac-myelin peptides by chemical conjugation. (a)-(c) Cross-linked products of Ac-myelin before enrichment: (a) structural illustration of cross-linked peptides, $\mathrm{R}$ represents either an additional peptide for inter-linked or a hydroxyl group for a dead-end modified Ac-myelin peptides; MS spectra of (b) inter-link (observed: $[\mathrm{M}+6 \mathrm{H}]^{6+} 467.07,[\mathrm{M}+5 \mathrm{H}]^{5+}$ 560.29, $[\mathrm{M}+4 \mathrm{H}]^{4+}$ 700.11; theoretical: $[\mathrm{M}+6 \mathrm{H}]^{6+} 467.07,[\mathrm{M}+5 \mathrm{H}]^{5+} 560.29,[\mathrm{M}+4 \mathrm{H}]^{4+} 700.11$ ); (c) dead-end (observed: $[\mathrm{M}+3 \mathrm{H}]^{3+}$ 508.26; theoretical: $[\mathrm{M}+3 \mathrm{H}]^{3+}$ 508.25) modified Ac-myelin. (d)-(i) Cross-linked products of Ac-myelin after copper catalyzed click chemistry (d)-(f), and affinity purification/TFA cleavage (h)-(i): (d) structural illustration of conjugated products after click chemistry; MS spectra of (e) inter-linked (observed: $[\mathrm{M}+6 \mathrm{H}]^{6+} 594.48,[\mathrm{M}+5 \mathrm{H}]^{5+} 713.18,[\mathrm{M}+$ $4 \mathrm{H}]^{4+}$ 891.21; theoretical: $[\mathrm{M}+6 \mathrm{H}]^{6+}$ 594.47, $[\mathrm{M}+5 \mathrm{H}]^{5+}$ 713.16, $\left.[\mathrm{M}+4 \mathrm{H}]^{4+} 891.20 ;\right)$ and (f) dead-end (observed: $[\mathrm{M}+3 \mathrm{H}]^{3+}$ 763.06; theoretical: $[\mathrm{M}+3 \mathrm{H}]^{3+}$ 763.05) products; $(\mathrm{g})$ structural illustration of final cross-linked products after affinity purification and TFA cleavage; MS spectra of (h) inter-linked (observed: $[\mathrm{M}+6 \mathrm{H}]^{6+} 490.28,[\mathrm{M}+5 \mathrm{H}]^{5+}$ 588.13, $[\mathrm{M}+4 \mathrm{H}]^{4+} 734.92$; theoretical: $[\mathrm{M}+6 \mathrm{H}]^{6+} 490.26$, $[\mathrm{M}+5 \mathrm{H}]^{5+} 588.11,[\mathrm{M}+4 \mathrm{H}]^{4+} 734.88$;) and (i) dead-end (observed: $[\mathrm{M}+3 \mathrm{H}]^{3+}$ 554.65; theoretical: $[\mathrm{M}+3 \mathrm{H}]^{3+}$ 554.62) modified peptides. (j)-(o) Cross-linked products of Ac-myelin after Staudinger ligation (j)-(1) and affinity purification/TFA cleavage (m)-(o): (j) structural illustration of Staudinger ligation conjugates; MS spectra of (e) inter-linked (observed: $[\mathrm{M}+6 \mathrm{H}]^{6+} 609.96$, $[\mathrm{M}+5 \mathrm{H}]^{5+} 728.16$, $[\mathrm{M}+4 \mathrm{H}]^{4+}$ 909.94; theoretical: $[\mathrm{M}+6 \mathrm{H}]^{6+}$ 609.96, $[\mathrm{M}+5 \mathrm{H}]^{5+} 728.15,[\mathrm{M}+4 \mathrm{H}]^{4+}$ 909.94) and (f) dead-end (observed: $[\mathrm{M}+3 \mathrm{H}]^{3+} 788.03$; theoretical: $\left.[\mathrm{M}+3 \mathrm{H}]^{3+} 788.03\right)$ products; $(\mathrm{m})$ structural illustration of the final cross-linked peptides after affinity purification and TFA cleavage; MS spectra of (n) inter-linked (observed: $[\mathrm{M}+6 \mathrm{H}]^{6+}$ 537.11, $[\mathrm{M}+5 \mathrm{H}]^{5+} 644.33$, $[\mathrm{M}+4 \mathrm{H}]^{4+}$ 805.15; theoretical: $[\mathrm{M}+6 \mathrm{H}]^{6+}$ 537.10, $[\mathrm{M}+5 \mathrm{H}]^{5+}$ 644.32, $[\mathrm{M}+4 \mathrm{H}]^{4+}$ 805.15) and (o) dead-end (observed: $[\mathrm{M}+4 \mathrm{H}]^{4+}$ 486.49; theoretical: $\left.[\mathrm{M}+4 \mathrm{H}]^{4+} 486.49\right)$ modified peptides. Note: (e), (f), (h), and (i) were acquired by QSTAR MS. The rest of MS spectra were acquired by LTQ-Orbitrap XL MS.

reaction. All of the cross-linked Ac-myelin can be conjugated with biotin-phosphine even at room temperature since no unconjugated Ac-myelin cross-linking product was detected, similar to that of copper catalyzed click reaction. However the conversion rate appears to be much faster at elevated temperature $\left(\sim 60{ }^{\circ} \mathrm{C}\right)$, and this could be advantageous for real protein samples with limited concentrations to obtain efficient conjugation. The structural illustrations and MS spectra of Staudinger products of cross-linked Ac-myelin before and after affinity purification/TFA cleavage are displayed in Figure $3 \mathbf{j}-0$. As shown, a series of multiply charged ions $\left([\mathrm{M}+6 \mathrm{H}]^{6+}\right.$ 606.96, $[\mathrm{M}+5 \mathrm{H}]^{5+}$ 728.16, $[\mathrm{M}+$ $4 \mathrm{H}]^{4+}$, 909.94) were detected as the conjugate of the inter-linked Ac-myelin (Figure 3k). TFA cleavage of the affinity purified conjugates resulted in a loss of $419.15 \mathrm{Da}$, and the final product of inter-link Acmyelin was measured as $[\mathrm{M}+6 \mathrm{H}]^{6+} 537.11,[\mathrm{M}+$ $5 \mathrm{H}]^{5+}$ 644.33, and $[\mathrm{M}+4 \mathrm{H}]^{4+} 805.15$ (Figure 3n). Similarly, Staudinger products of the dead-end Acmyelin before and after TFA cleavage were detected as $[\mathrm{M}+3 \mathrm{H}]^{3+} 788.03$ (Figure $3 \mathrm{l}$ ) and $[\mathrm{M}+4 \mathrm{H}]^{4+}$ 486.49 (Figure 3o), respectively. The final mass addition on cross-linked peptides attributed to the conjugated cross-linker after TFA cleavage are 
649.26 Da (i.e., $\mathrm{C}_{34} \mathrm{H}_{40} \mathrm{~N}_{3} \mathrm{O}_{8} \mathrm{P}$ ) for dead-end modification, and 631.24 Da (i.e., $\mathrm{C}_{34} \mathrm{H}_{38} \mathrm{~N}_{3} \mathrm{O}_{7} \mathrm{P}$ ) for both intra-linked and inter-linked ones.

Similar experiments were carried out using another model peptide Ac-IR7 in organic solvent to limit crosslinker hydrolysis. Cross-linking of the Ac-IR7 peptide, selective enrichment and release of the cross-linked Ac-IR7 peptides were as efficient as Ac-myelin (Supplemental Figure 1). In comparison with the copper catalyzed click chemistry, this approach has similar conversion efficiency, but precipitation can be completely avoided and background reactions were largely suppressed. Therefore, the Staudinger ligation has been selected as the method for enrichment of azide-containing cross-linked peptides in the sections described below.

\section{Capture of a Cross-Linked Model Peptide from a Protein Digest Mixture}

To test the effectiveness of the enrichment of azide-DSG cross-linked peptides in a mixture, we mixed azideDSG cross-linked Ac-myelin with chicken lysozyme tryptic digest in a 1:1 ratio. The peptide mixture was subjected to Staudinger conjugation, then affinity purified and eluted by TFA. This process was monitored by LC MS analysis at each step as seen in Figure 4. As shown, the Ac-myelin cross-linked peptides (i.e., interlinked and dead-end) were not the most abundant species either before (Figure 4a) or after Staudinger ligation (Figure $4 \mathrm{~b}$ ). However, after affinity purification and acid cleavage elution, both inter-linked and deadend products were successfully isolated and the interlinked Ac-myelin became the second most abundant signal in the purified sample (Figure 4c). This result demonstrates the effectiveness of the selective isolation of azide-tagged cross-linked peptides from a peptide mixture. Due to the presence of the acid cleavage site in the biotin-phosphine, the excess biotin-phosphine used in the reaction that bound to the streptavidin beads was also present in the final elution, thus leading to undesirable signals, including the most abundant peak (labeled with an asterisk "**) in the sample (Figure 4c). Since the excess biotin-phosphine elutes at a particular time point as a distinct peak at the end of the gradient (Figure 4c), its possible interference would be limited to its co-eluting peptides. However, no obvious hindrance has been observed for MS analysis of cross-linked peptides due to excess biotin-phosphine. Ultimately, elimination of these impurities is desirable and can be accomplished by incorporating an acid cleavage site in the cross-linkers. This is currently under investigation.

\section{$M S^{n}$ Analysis to Facilitate Identification of Cross-Linked Peptides}

To confirm the cross-linked products, MS/MS analyses were first carried out. As an example, the MS/MS
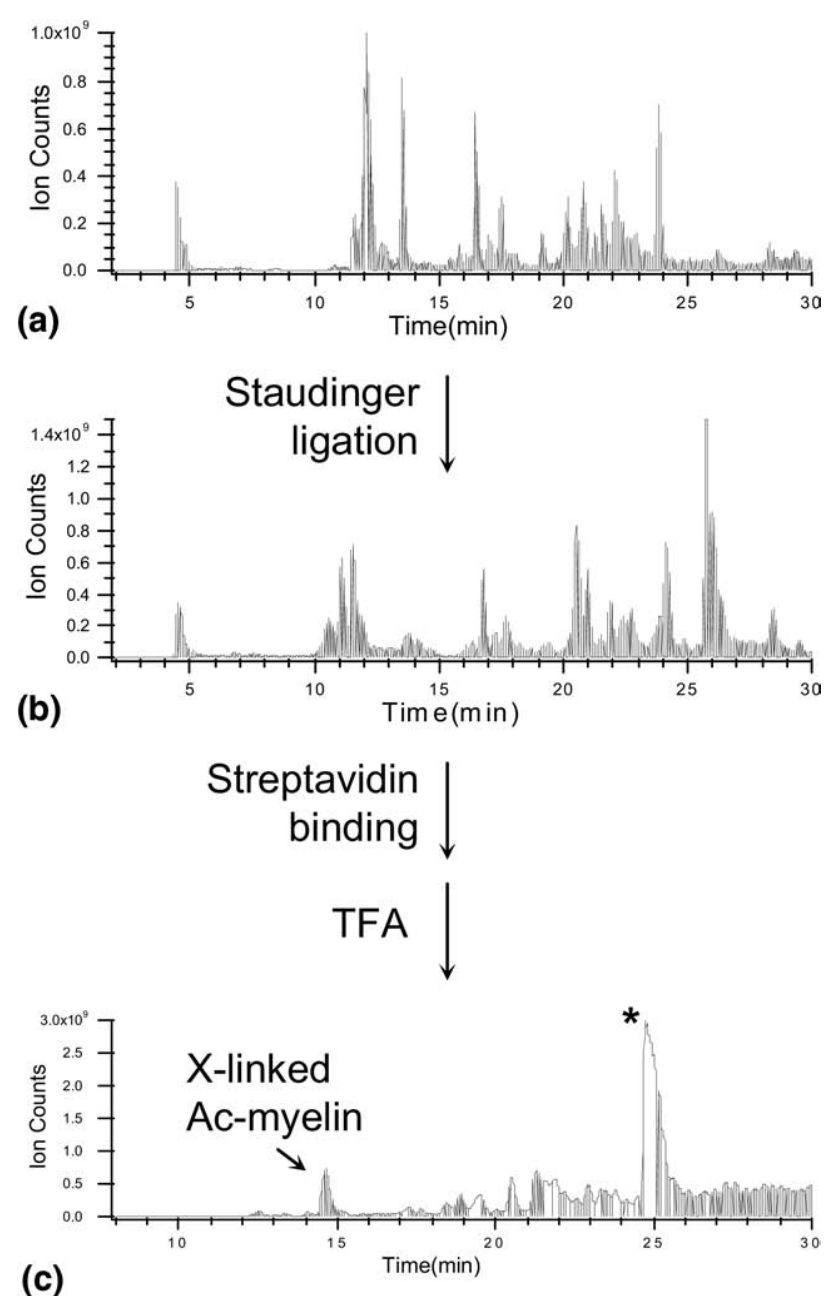

Figure 4. Enrichment of cross-linked Ac-myelin peptides after its mixing with a Lysozyme digest (1:1) using Staudinger ligation. LC MS traces of peptide mixtures: (a) before (inter-linked and deadend modified Ac-myelin eluted at 11.6 and $11.2 \mathrm{~min}$, respectively) and (b) after (inter-linked and dead-end modified Ac-myelin eluted at 20.1 and $26.4 \mathrm{~min}$, respectively) Staudinger ligation; (c) after affinity purification and TFA cleavage elution. X-linked Ac-myelin (14.4 min) indicates the enriched inter-linked peptide. ${ }^{*}$ Cleaved biotin-phosphine products. The dead-end modified Acmyelin eluted at $16.8 \mathrm{~min}$.

spectrum of an inter-linked Ac-myelin product ([M + $5 \mathrm{H}]^{5+} 644.33$ ) after enrichment, purification, and elution is illustrated in Figure $5 \mathrm{a}$, in which two sets of major ions were observed. One set of the ions (i.e., $[\mathrm{M}+4 \mathrm{H}]^{4+}$ $670.85,675.36,678.36)$ were the fragment ions resulting from the parent ion $\left([\mathrm{M}+5 \mathrm{H}]^{5+} 644.33\right)$, with a loss of $538.2,520.2$, and $508.2 \mathrm{Da}$, respectively. Two of the corresponding losses (i.e., $\mathrm{MH}^{+} 520.24$ and 508.24) and another fragment ion with $\mathrm{MH}^{+} 447.19$ were observed as the second set of ions (labeled as I, II, and III) in Figure 5a. The fragment ion with $\mathrm{MH}^{+} 538.2$ was often not detected due to its further fragmentation into its water loss product ion $\left(\mathrm{MH}^{+}\right.$520.2). Similarly, in the MS/MS spectrum of the inter-linked Ac-IR7 after enrichment and purification (Figure 5b), two sets of fragment ions were observed, including one set of ions with 
(a)


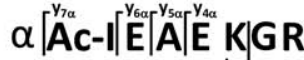

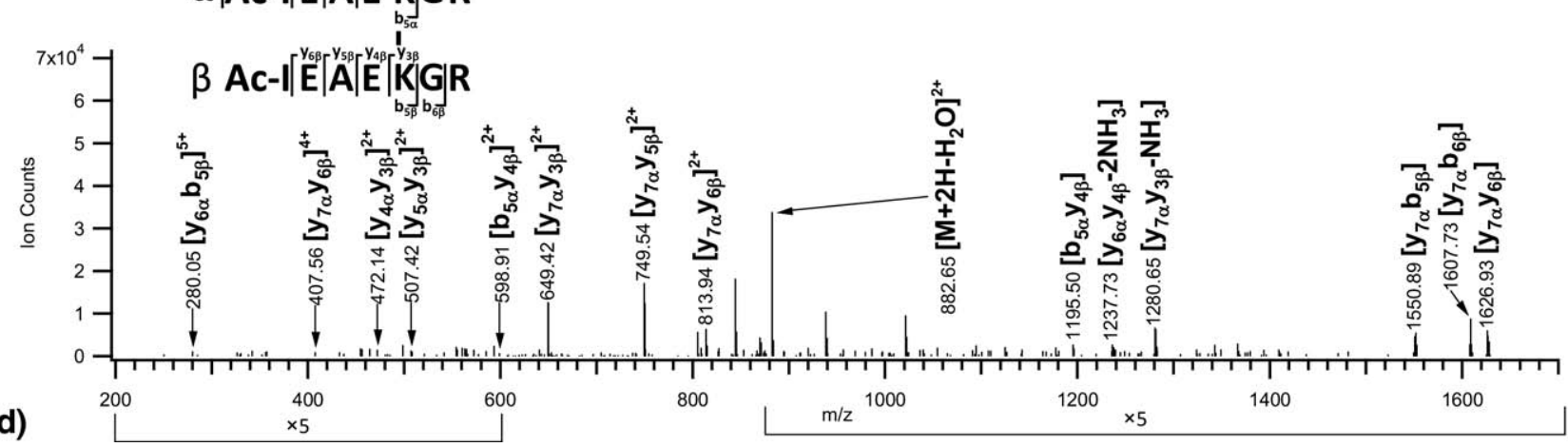

Figure 5. $\mathrm{MS}^{n}$ analyses of inter-linked Ac-myelin and Ac-IR7 after Staudinger ligation and affinity purification/TFA cleavage. MS/MS spectra of (a) inter-linked Ac-myelin ([M + 5H $\left.]^{5+} 644.33\right)$; and (b) inter-linked Ac-IR7 $\left([\mathrm{M}+3 \mathrm{H}]^{3+}\right.$ 773.73) peptides. $\mathrm{MS}^{3}$ spectra of $(\mathrm{c})$ a fragment ion $\left([\mathrm{M}+4 \mathrm{H}]^{4+}\right.$, $670.85)$ after a loss of $538.2 \mathrm{Da}$ from the parent ion $\left([\mathrm{M}+5 \mathrm{H}]^{5+} 644.34\right)$ observed in (a); and (d) a fragment ion $\left([\mathrm{M}+2 \mathrm{H}]^{2+} 891.83\right)$ after a loss of $538.2 \mathrm{Da}$ from the parent ion $\left([\mathrm{M}+3 \mathrm{H}]^{3+} 773.73\right)$ observed in (b). Characteristic fragment ions in MS/MS spectra, i.e., 447.2, 508.2, and 520.2 were detected due to fragmentation in the cross-linker region and their structures are displayed in Supplemental Figure 2.

$\mathrm{MH}^{+} 447.28$, 508.23, and 520.18, and another set of fragment ions with $[\mathrm{M}+2 \mathrm{H}]^{2+} 891.83,900.54,906.47$, corresponding to the parent ion $\left([\mathrm{M}+3 \mathrm{H}]^{3+} 773.73\right)$ with a loss of 538.2, 520.2, or $508.2 \mathrm{Da}$, respectively. Similar fragmentation pattern was detected in both dead-end modified Ac-myelin and Ac-IR7 peptides (Supplemental Figure 2). Taken together, the results suggest that this type of fragmentation is unique to the cross-linked peptides, and detection of a group of the fragment ions (i.e., $\mathrm{MH}^{+} 447.2,508.2$, and 520.2) is independent of the type and sequence of the crosslinked peptides. This prompted us to believe that such fragmentation is due to unique bond cleavages at the conjugated cross-linker region during CID analysis. The proposed cleavage sites in the conjugated cross-linker region and resultant structures of the fragmentation ions are depicted in Supplemental Figure 3. Therefore, these ions $\left(\mathrm{MH}^{+} 447.2,508.2,520.2\right)$ are characteristic fragmentation ions of cross-linked products after Staudinger ligation and affinity purification/TFA cleavage, and can be used as diagnostic markers to facilitate the identification of cross-linked peptides by MS/MS.

Due to the preferential bond cleavages at the linker region, limited fragmentation on the peptide backbone was observed in MS/MS spectra. To obtain detailed sequence information, $\mathrm{MS}^{3}$ analyses of the parent ions after their characteristic losses were further performed. Figure $5 \mathrm{c}$ displays the $\mathrm{MS}^{3}$ spectrum of the fragment ion $\left([\mathrm{M}+4 \mathrm{H}]^{4+}\right.$ 670.85), which resulted from the parent inter-linked Ac-myelin $\left([\mathrm{M}+5 \mathrm{H}]^{5+}\right.$ 644.33) after a loss 
of 538.2 Da as measured in Figure 5a. Based on the previously described terminology of inter-linked peptides and their fragment ions [8], we have labeled one sequence of the inter-linked Ac-myelin as the $\alpha$ chain and the other as the $\beta$ chain. In addition to fragment ions belonging to $\alpha$ or $\beta$ chain sequence, fragment ions containing both chains were detected. The masses of all possible fragment ions of the inter-linked Ac-myelin were calculated, which were then manually matched to the observed ions in Figure $5 c$ for unambiguous identification of the inter-linked Ac-myelin sequence. Similarly, $\mathrm{MS}^{3}$ analysis of the fragment ion $\left([\mathrm{M}+2 \mathrm{H}]^{2+}\right.$ 891.83) of the parent inter-linked Ac-IR7 ion ([M + $3 \mathrm{H}]^{3+}$ 773.73) after a loss of 538.2 Da (Figure 5b) confirmed its sequence as illustrated in Figure $5 \mathrm{~d}$.

\section{Enrichment and Identification of Cytochrome c Cross-Linked Peptides}

To determine whether the cross-linking enrichment strategy can be applied to more complex samples, cytochrome $c$ was used as a model protein since it has been widely used in other cross-linking experiments [3, 8, 40, 41, 65-68]. Cytochrome $c$ was cross-linked using azide-DSG and the cross-linked products were separated by 1-D SDS-PAGE. Various molar ratios of azideDSG and cytochrome $c(10: 1,15: 1 ; 20: 1,50: 1)$ were tested to optimize the cross-linking efficiency with tenfold excess of azide-DSG determined as the optimal ratio for final analyses. After cross-linking, the cross-linked cytochrome $c$ was digested in-solution with trypsin and the tryptic peptides were subjected to Staudinger ligation using the biotin-phosphine (S-17) as described above (Figures 1 and 2). The resulting conjugates were then affinity purified, eluted with TFA, and analyzed by LC MS/MS. In comparison with model peptides, data processing of cross-linked cytochrome $c$ peptides was much more complicated due to the presence of a large number of heterogeneous and unknown cross-linked peptides. To facilitate the data interpretation, we have employed a suite of software (i.e., Batch-tag, MS-bridge, MS-tag, MS-product and Search Compare) in Protein Prospector to identify cytochrome $c$ peptides via a method similar to that previously described [62]. MS/MS spectra were first searched against cytochrome $c$ sequence using Batch-tag with mass modification search to identify unmodified peptides as well as peptides with various mass modifications. Our cross-linker targets lysine residues and the free protein N-terminus, therefore we considered these residues as potential sites for mass modifications [62]. For dead-end (type 0) modified and intra-linked (type 1) peptides, defined mass modifications on lysine residues, i.e., 649.26 and 631.24 Da, would be observed, respectively. These masses are attributed to the addition of cross-links on the peptides due to the cross-linking nature of the type 0 and 1 products [8], which can be used for their identification. However, for inter-linked peptides, the mass modification would be undefined since it contains both the cross-link (i.e., 631.24 Da) and an additional covalently attached peptide. Even with mass modification search, most of the cross-linked peptides were not identified by Batch-tag search. This is a result of the complicated fragmentation in MS/MS spectra caused by preferred cleavage at the conjugated linker region and the presence of an additional sequence in the inter-linked peptides.

To determine the cross-linked peptide identities, three additional steps were carried out. First, the monoisotopic masses and charges of all parent ions selected for MS/MS were subjected to the MS-bridge program to identify putative azide-DSG cross-linked peptides of cytochrome $c$ by peptide mass mapping with high mass accuracy ( $<20 \mathrm{ppm}$ ) [62]. Second, we manually examined MS/MS spectra of the putative cross-linked cytochrome $c$ peptides identified in MSbridge to determine whether the diagnostic fragment ions $\left(\mathrm{MH}^{+}, 447.2,508.2,520.2\right)$ of the conjugated crosslink were observed. Third, MS-tag, MS-product and manual inspection were performed to identify and confirm the cross-linked peptide sequences and correlate them with MS-bridge search results. For instance, based on MS-bridge search results, an ion with [M + $4 \mathrm{H}]^{4+} 542.54$ matched to an inter-linked peptide [AcGDVEKGK inter-linked to KIFVQK], an ion with [M + $3 \mathrm{H}]^{3+} 526.96$ matched to an intra-linked peptide [GK(631.24)KIFVQK], and an ion with $[\mathrm{M}+3 \mathrm{H}]^{3+}$ 745.34 matched to a dead-end product $[\mathrm{K}(649.26)$ TGQAPGFSYTDANK]. Consistent with cross-linked model peptides (Figure 5a and b, and Supplemental Figure 2), all of the putative cross-linked cytochrome $c$ peptides gave same characteristic fragment ions $\left(\mathrm{MH}^{+}\right.$ 447.2, 508.2, and 520.2) in their MS/MS spectra as illustrated in Figure $6 \mathrm{a}-\mathrm{c}$, suggesting that these peptides are indeed enriched cross-linked products. Additionally, the corresponding fragment ions of parent ions with a loss of 508.2 or 520.2 Da were observed in their MS/MS spectra (Figure 6a-c).

In addition to MS/MS experiments, $\mathrm{MS}^{3}$ analyses of selected fragment ions observed in MS/MS spectra of these three cross-linked cytochrome $c$ peptides (Figure $6 a-c)$ were carried out to further confirm their identities. For the inter-linked peptide $\left([\mathrm{M}+4 \mathrm{H}]^{4+}\right.$ 542.54), its fragment ion with $[\mathrm{M}+2 \mathrm{H}]^{2+} 824.72$ (Figure 6a) was selected for $\mathrm{MS}^{3}$ analysis. The loss of $520.2 \mathrm{Da}$ from the parent ion $\left([\mathrm{M}+4 \mathrm{H}]^{4+} 542.54\right)$ led to a mass modification of $112 \mathrm{Da}$ on the inter-linked fragment ion ([M + $2 \mathrm{H}]^{2+} 824.72$ ) due to the remnant of the conjugated link (see Supplemental Figure 3). As shown in Figure 6d, a series of $b$ and $y$ ions for either a single or both peptide chains were observed in the $\mathrm{MS}^{3}$ spectrum of $[\mathrm{M}+$ $2 \mathrm{H}]^{2+} 824.72$, further confirming the inter-linked peptide sequences identified by MS-bridge. For the intralinked peptide $\left([\mathrm{M}+3 \mathrm{H}]^{3+} 526.96\right)$, the fragment ion with $[\mathrm{M}+2 \mathrm{H}]^{2+} 536.31$ (Figure $6 \mathrm{~b}$ ) was analyzed by $\mathrm{MS}^{3}$, which has a mass modification of 124 Da due to the loss of 508.2 Da from its intra-linked parent ion. In 
(a)

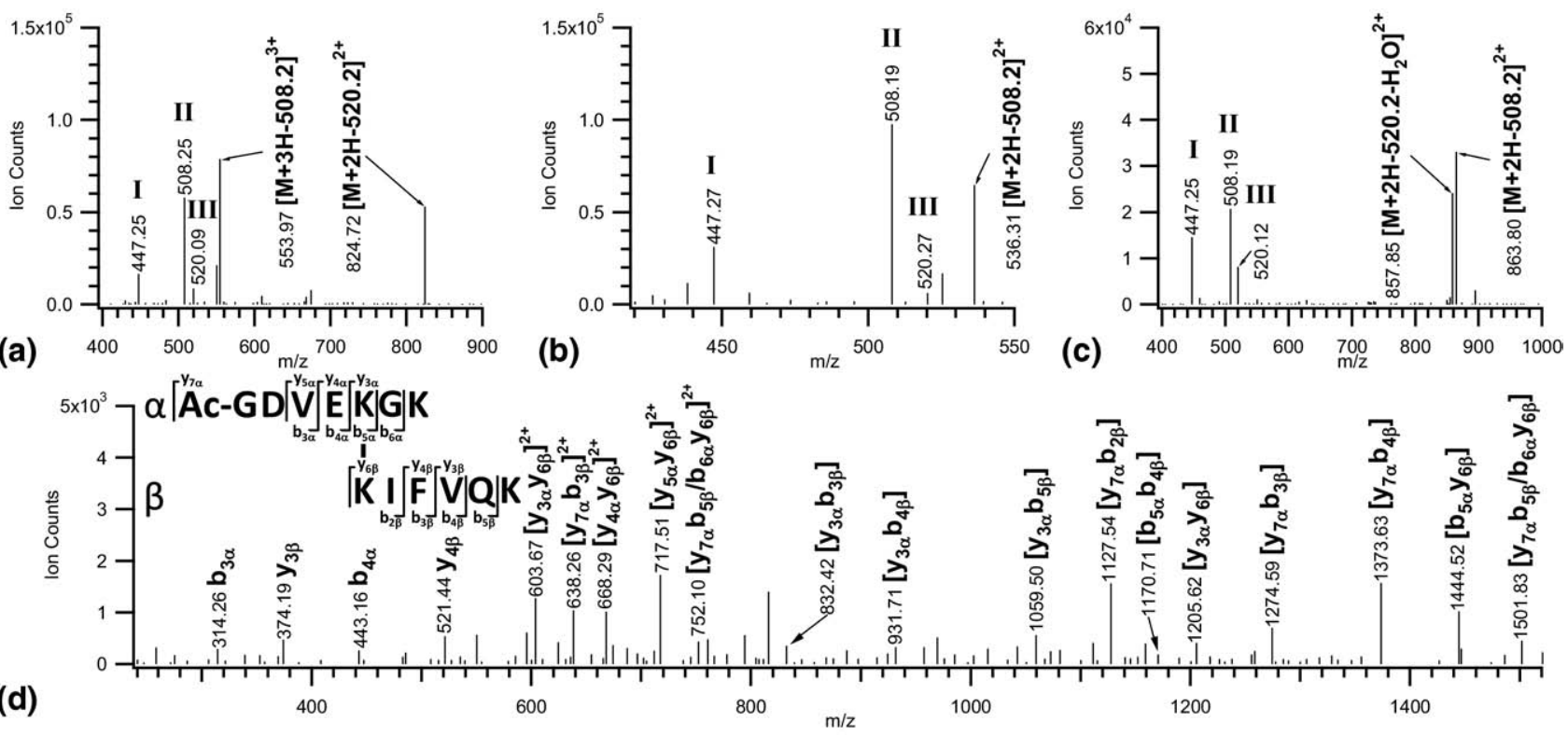

(d)

(e)
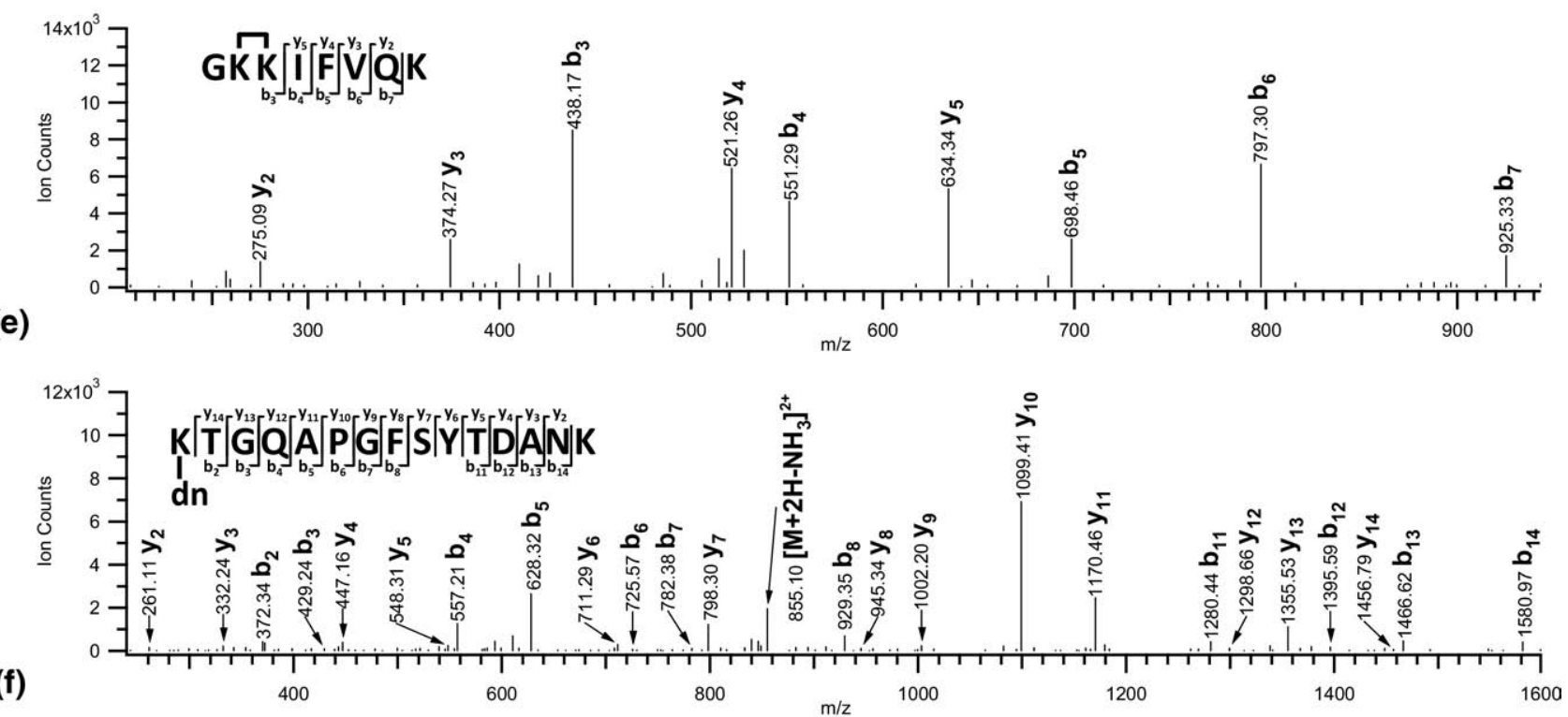

Figure 6. $\mathrm{MS}^{n}$ analyses of three azide-DSG cross-linked peptides of cytochrome $c$ after Staudinger ligation and affinity purification/TFA cleavage. MS/MS spectra of the selected (a) inter-linked ([M + $4 \mathrm{H}]^{4+}$ 542.54); (b) intra-linked ([M $\left.\left.+3 \mathrm{H}\right]^{3+} 526.96\right)$; and (c) dead-end $\left([\mathrm{M}+3 \mathrm{H}]^{3+} 745.35\right)$ modified peptides. Characteristic fragment ions $\left(\mathrm{MH}^{+} 447.2,508.2,520.2\right)$ were detected in all spectra. $\mathrm{MS}^{3}$ spectra of $(\mathbf{d})$ a fragment ion $\left([\mathrm{M}+2 \mathrm{H}]^{2+}\right.$ 824.72) observed in (a), after a loss of $508.2 \mathrm{Da}$ from the parent ion $\left([\mathrm{M}+4 \mathrm{H}]^{4+} 542.54\right)$; (e) a fragment ion $\left([\mathrm{M}+2 \mathrm{H}]^{2+}\right.$ 536.31) observed in (b), after a loss of $508.2 \mathrm{Da}$ from the parent ion $\left([\mathrm{M}+3 \mathrm{H}]^{3+} 526.96\right)$; and (f) a fragment ion $\left([\mathrm{M}+2 \mathrm{H}]^{2+} 863.80\right)$ observed in (c), after a loss of 508.2 Da from the parent ion $\left([\mathrm{M}+3 \mathrm{H}]^{3+} 745.35\right)$. The identified cross-linked peptide sequences are displayed in (d)-(f). $\mathrm{dn}=$ dead-end modification.

the $\mathrm{MS}^{3}$ spectrum of $[\mathrm{M}+2 \mathrm{H}]^{2+} 536.31$ (Figure 6e), detection of $\mathrm{y}_{2}-\mathrm{y}_{5}$ and $\mathrm{b}_{3}-\mathrm{b}_{7}$ ion series allowed unambiguous identification of the intra-linked peptide as GKKIFVQK, in which the two adjacent lysine residues at the $\mathrm{N}$-terminus were determined to be cross-linked. Similar fragmentation was also observed in the $\mathrm{MS}^{3}$ spectrum (Figure 6f) of a MS/MS fragment ion with $[\mathrm{M}+2 \mathrm{H}]^{2+} 863.80$ (Figure 6c) from the dead-end modified parent ion $\left([\mathrm{M}+3 \mathrm{H}]^{3+} 745.35\right)$ after a loss of 508.2 Da. As shown, $\mathrm{y}_{2}-\mathrm{y}_{14}$ and $\mathrm{b}_{2}-\mathrm{b}_{14}$ ions confirmed the dead-end modified peptide with a sequence of $\mathrm{K}(\mathrm{dn}) T$ GQAPGFSYTDANK, in which the N-terminal lysine was modified.

In this work, although all of the cross-linked peptides have given characteristic losses in MS/MS for their identification, we were only able to interpret four additional $\mathrm{MS}^{3}$ spectra, including two inter-linked and two intra-linked cytochrome $c$ peptides as displayed in Supplemental Figures 4 and 5 . This is due to lower sensitivity in MS $^{3}$ and lack of software for effective 
Table 1. Summary of identified cross-linked peptides of cytochrome $c$ after enrichment

\begin{tabular}{|c|c|c|c|c|c|c|c|}
\hline Type & Peptide sequence & AA location & $\begin{array}{c}\mathrm{m} / \mathrm{z} \\
\text { (Observed) }\end{array}$ & z & $\Delta(\mathrm{ppm})$ & $\begin{array}{l}\text { Seen before } \\
\text { enrichment }\end{array}$ & References \\
\hline 0 & Ac-GDVEKGK & G1-K7 & 712.3342 & 2 & 5 & Yes & \\
\hline 0 & Ac-GDVEKGKK & G1-K8 & 517.9262 & 3 & 9 & Yes & \\
\hline 0 & KIFVQK & K8-K13 & 706.3799 & 2 & 7 & Yes & {$[40,41,67]$} \\
\hline 0 & GGKHK & G23-K27 & 588.2895 & 2 & 6 & Yes & \\
\hline \multirow[t]{2}{*}{0} & KTGQAPGFSYTDANK & K39-K53 & $745.3507^{*}$ & 3 & 7 & Yes & {$[40,41,66,67]$} \\
\hline & & & 559.2618 & 4 & 2 & Yes & \\
\hline \multirow[t]{2}{*}{0} & KTGQAPGFSYTDANKNK & K39-K55 & 826.0621 & 3 & 5 & Yes & {$[40,65,66,67]$} \\
\hline & & & 619.7963 & 4 & 1 & Yes & \\
\hline \multirow[t]{2}{*}{0} & KYIPGTK & K73-K79 & 728.3737 & 2 & 5 & Yes & {$[41,67]$} \\
\hline & & & 485.9183 & 3 & 5 & Yes & \\
\hline 0 & KGER & K88-R91 & 569.7707 & 2 & 1 & Yes & \\
\hline \multirow[t]{2}{*}{0} & EDLIAYLKK & E92-K100 & 871.4472 & 2 & 1 & Yes & [67] \\
\hline & & & 581.3033 & 3 & 5 & Yes & \\
\hline 0 & KATNE & K100-E104 & 606.2740 & 2 & 2 & Yes & \\
\hline 1 & Ac-GDVEKGKK & G1-K8 & 767.3693 & 2 & -5 & No & \\
\hline 1 & Ac-GDVEKGKKIFVOK & G1-K13 & 717.0482 & 3 & 7 & Yes & \\
\hline \multirow[t]{3}{*}{1} & GKKIFVOK & G6-K13 & 789.9327 & 2 & 6 & Yes & {$[41,66,67]$} \\
\hline & & & $526.9579 *$ & 3 & 5 & Yes & \\
\hline & & & 395.4689 & 4 & 3 & Yes & \\
\hline \multirow[t]{3}{*}{1} & GGKHKTGPNLHGLFGR & G23-R38 & 769.7238 & 3 & -1 & Yes & {$[8,40,41,66,67]$} \\
\hline & & & $577.5500 *$ & 4 & 8 & Yes & \\
\hline & & & 462.2401 & 5 & 5 & Yes & \\
\hline \multirow[t]{3}{*}{1} & GGKHKTGPNLHGLFGRK & G23-K39 & 609.5687 & 4 & -1 & Yes & {$[66,67]$} \\
\hline & & & 487.8605 & 5 & 7 & Yes & \\
\hline & & & 406.7162 & 6 & 3 & Yes & \\
\hline \multirow[t]{3}{*}{1} & KTGQAPGFSYTDANKNK & K39-K55 & 1229.5850 & 2 & 6 & Yes & {$[8,40,41,66,68]$} \\
\hline & & & 820.0587 & 3 & 5 & Yes & \\
\hline & & & 615.2941 & 4 & 2 & Yes & \\
\hline \multirow[t]{2}{*}{1} & MIFAGIKKK & M80-K88 & 833.9532 & 2 & 10 & Yes & {$[8,40,41,66,67]$} \\
\hline & & & 556.2999 & 3 & 1 & Yes & \\
\hline \multirow[t]{2}{*}{1} & MoxIFAGIKKK & M80-K88 & 841.9451 & 2 & 3 & Yes & \\
\hline & & & $561.6340^{*}$ & 3 & 5 & Yes & \\
\hline \multirow[t]{2}{*}{1} & KKGER & K87-R91 & 624.8149 & 2 & 4 & Yes & {$[41]$} \\
\hline & & & 416.8803 & 3 & 6 & Yes & \\
\hline \multirow[t]{2}{*}{1} & GEREDLIAYLKKATNE & G89-E104 & 827.7458 & 3 & 5 & Yes & \\
\hline & & & 621.0619 & 4 & 6 & Yes & \\
\hline \multirow[t]{2}{*}{1} & EDLIAYLKKATNE & E92-E104 & 1070.0338 & 2 & 7 & Yes & [67] \\
\hline & & & 713.6908 & 3 & 6 & Yes & \\
\hline \multirow[t]{2}{*}{2} & Ac-GDVEKGK & $\mathrm{G} 1-\mathrm{K} 7 \sim \mathrm{K} 8-\mathrm{K} 13$ & 723.0504 & 3 & 6 & Yes & {$[3,40,41,67]$} \\
\hline & KIFVOK & & $542.5392^{*}$ & 4 & 5 & Yes & \\
\hline \multirow[t]{2}{*}{2} & Ac-GDVEKGK & $\mathrm{G} 1-\mathrm{K} 7 \sim \mathrm{K} 87-\mathrm{K} 88$ & 560.6229 & 3 & 6 & Yes & {$[67,68]$} \\
\hline & KK & & 420.7197 & 4 & 7 & Yes & \\
\hline 2 & $\begin{array}{l}\text { Ac-GDVEKGK } \\
\text { KKGER }\end{array}$ & G1-K7 K87-R91 & 506.2615 & 4 & 7 & Yes & {$[67,68]$} \\
\hline 2 & Ac-GDVEKGKK & $\mathrm{G} 1-\mathrm{K} 8 \sim \mathrm{K} 87-\mathrm{K} 88$ & 452.7451 & 4 & 10 & Yes & [67] \\
\hline & KK & & & & & & \\
\hline 2 & Ac-GDVEKGKK & G1-K8 K87-R91 & 538.2844 & 4 & 5 & Yes & {$[67,68]$} \\
\hline 2 & $\begin{array}{l}\text { KKGER } \\
\text { GKK }\end{array}$ & G6-K8 K88-R91 & & & & & \\
\hline 2 & $\begin{array}{l}\text { GKK } \\
\text { KGER }\end{array}$ & G6-K8 K88-R91 & 726.3632 & 2 & -17 & Yes & \\
\hline 2 & GKK & $\mathrm{G} 6-\mathrm{K} 8 \sim \mathrm{K} 100-\mathrm{E} 104$ & $762.8826^{*}$ & 2 & 6 & Yes & {$[66,68]$} \\
\hline & KATNE & & 508.9219 & 3 & 1 & Yes & \\
\hline & & & 381.9450 & 4 & 5 & Yes & \\
\hline 2 & KIFVOK & K8-K13 K100-E104 & 652.3468 & 3 & 9 & Yes & \\
\hline & KATNE & & 489.5106 & 4 & 6 & Yes & \\
\hline 2 & GGKHK & K23-K27 K100-E104 & $573.6183^{*}$ & 3 & 6 & Yes & \\
\hline & KATNE & & & & & & \\
\hline 2 & KTGQAPGFSYTDANK & K39-K53 M80-K88 & 813.4261 & 4 & 13 & No & \\
\hline & MIFAGIKKK & & 650.9429 & 5 & 13 & No & \\
\hline 2 & KTGQAPGFSYTDANK & K39-K53 K100-E104 & 695.0784 & 4 & 2 & Yes & {$[67,68]$} \\
\hline & KATNE & & & & & & \\
\hline
\end{tabular}


Table 1. Continued

\begin{tabular}{|c|c|c|c|c|c|c|c|}
\hline Type & Peptide sequence & AA location & $\begin{array}{c}\mathrm{m} / \mathrm{z} \\
\text { (Observed) }\end{array}$ & $\mathrm{z}$ & $\Delta(\mathrm{ppm})$ & $\begin{array}{l}\text { Seen before } \\
\text { enrichment }\end{array}$ & References \\
\hline 2 & $\begin{array}{l}\text { KKGER } \\
\text { KATNE }\end{array}$ & K87-R91 K100-E104 & 453.2339 & 4 & 11 & Yes & \\
\hline 2 & $\begin{array}{l}\text { KGER } \\
\text { KATNE }\end{array}$ & K88-R91 K100-E104 & 561.2752 & 3 & 7 & Yes & \\
\hline 2 & $\begin{array}{l}\text { KATNE } \\
\text { KATNE }\end{array}$ & K100-E104 K100-E104 & 585.6121 & 3 & 10 & Yes & \\
\hline
\end{tabular}

All of the cross-linked peptides have displayed characteristic losses in MS/MS.

*These cross-linked peptides have been further confirmed by MS3.

searching of $\mathrm{MS}^{3}$ spectra with complex fragmentation, which result from cross-linked peptides. Further software development that allows automated interpretation of $\mathrm{MS}^{3}$ spectra of enriched cross-linked peptides will significantly facilitate the identification process by peptide sequencing and increase the confidence of sequence assignments.

As summarized in Table 1, 14 dead-end modified (type 0), 24 intra-linked (type 1), and 20 inter-linked (type 2) peptides of cytochrome $c$ have been identified from our new enrichment strategy using Staudinger ligation. This represents 35 unique cytochrome $c$ crosslinked sequences, among which 19 have been previously reported using other NHS ester cross-linking reagents $[3,8,40,41,65-68]$, and 16 were first identified in this study. To have a better comparison, we have summarized a combined non-redundant list of interlinked, intra-linked, and dead-end modified lysine residues of bovine cytochrome $c$ identified in this work and other reports $[3,8,65,66,68]$ (Supplemental Table 1). As shown, a total of 19 putative inter-linked, 8 intra-linked, and 10 dead-end modified lysine residues have been identified by MS analyses using various cross-linkers. Among them, our study has identified 12 inter-linked lysines including eight new ones, eight intra-linked lysines including four new ones, and 10 dead-end modified lysines including nine new ones. The absence of a few previously reported linkages may be due to the facts that we have only listed out the cross-linked peptides with characteristic diagnostic ions in Table 1, which do not include peptides identified based solely on the $\mathrm{m} / \mathrm{z}$ and charge state as other papers had in the past. In addition, different cross-linkers with various spacer lengths and experimental conditions may result in identification of different peptides.

In comparison with the results before enrichment, the Staudinger ligation-based enrichment strategy has demonstrated its effectiveness in isolating cross-linked products. Based on the three-dimensional crystal structure of bovine heart cytochrome $c$ (PDB ID; 2B4Z) [69], we have calculated the $\alpha$ carbon distances between the cross-linked lysine residues identified in the crosslinked peptides. As shown in Supplemental Table 2, among 16 different combinations of type 1 or 2 crosslinked lysines in cytochrome $c$ identified in this work (not considering linkages between two adjacent ly- sines), 13 linkages have the distances between their $\alpha$ carbons within $20 \AA$, and 3 of them have the distances 21-25 $\AA$, which was measured using Jmol (http:/ / jmol.org/). This is consistent not only with the length of a fully expanded azide-DSG (7.7 A spacer length) and two lysine side chains, but also with the previous results using similar lengths of NHS ester cross-linkers $[39,67,70]$. The results suggest that our cross-linking condition did not induce significant disturbance to cytochrome $c$ structural conformations.

\section{Conclusion}

In this study, we have designed, synthesized, and evaluated a novel azide-tagged cross-linker, azide-DSG, which enables selective and effective enrichment of cross-linked peptides using Staudinger ligation. In comparison with other types of enrichment strategies using alkyne tags [39], the azide tag is more resistant to oxidative side reactions that could reduce the capture efficiency. Although azide-alkyne chemistry has been applied to capture azide-tagged cross-linked peptides [40, 41], we demonstrate that the new Staudinger ligation-based strategy is efficient for selective enrichment of the cross-linked peptides from complex mixtures, and is better suited for peptide analysis. In addition, the diagnostic ions $\left(\mathrm{MH}^{+} 447.2,508.2,520.2\right)$ detected in MS/MS spectra due to characteristic fragmentation in the conjugated link after Staudinger reaction and affinity purification offer a unique means for MS identification with increased confidence. This set of diagnostic ions is easy to detect and would be more reliable for identifying cross-linked peptides by MS in comparison with a diagnostic fragmentation with a neutral loss as employed in alkyne tagged cross-linked peptides [39]. Moreover, $\mathrm{MS}^{3}$ analysis permitted additional fragmentation information for unambiguous peptide identification. In comparison with immobilized cyclic alkyne [41], synthesis of biotin-phosphine is much simpler with only three steps. Taken together, the novel enrichment strategy developed in this work helps facilitate MS identification of cross-linked peptides from complex mixtures. With the development of bioinformatics tools, we anticipate that this approach can be easily generalized for capturing and identifying cross-linked peptides of protein complexes. 


\section{Acknowledgments}

The authors thank Drs. Christian Tagwerker and Lei Fang for initial analysis and members of the Huang and Rychnovsky laboratory for their help during this study. They thank Professor A.L. Burlingame, Peter Baker, and Aenoch Lynn at UCSF for using Protein Prospector. The authors acknowledge support for this work by National Institutes of Health grants (GM-74,830 to L.H.).

\section{Appendix A Supplementary Material}

Supplementary material associated with this article may be found in the online version at doi:10.1016/ j.jasms.2010.04.004.

\section{References}

1. Agou, F.; Ye, F.; Veron, M. In Vivo Protein Cross-Linking. Methods Mol. Biol. 2004, 261, 427-442.

2. Back, J. W.; de Jong, L.; Muijsers, A. O.; de Koster, C. G. Chemical Cross-Linking and Mass Spectrometry for Protein Structural Modeling. J. Mol. Biol. 2003, 331(2), 303-313.

3. Sinz, A. Chemical Cross-Linking and Mass Spectrometry for Mapping Three-Dimensional Structures of Proteins and Protein Complexes. J. Mass Spectrom. 2003, 38(12), 1225-1237.

4. Sinz, A. Chemical Cross-Linking and Mass Spectrometry to Map Three-Dimensional Protein Structures and Protein-Protein Interactions. Mass Spectrom. Rev. 2006, 25(4), 663-682.

5. Sinz, A. Investigation of Protein-Protein Interactions in Living Cells by Chemical Crosslinking and Mass Spectrometry. Anal. Bioanal. Chem. 2010, Jan 15 [Epub ahead of print].

6. Mouradov, D.; King, G.; Ross, I. L.; Forwood, J. K.; Hume, D. A.; Sinz, A.; Martin, J. L.; Kobe, B.; Huber, T. Protein Structure Determination Using a Combination of Cross-Linking, Mass Spectrometry, and Molecular Modeling. Methods Mol. Biol. 2008, 426, 459-474.

7. Young, M. M.; Tang, N.; Hempel, J. C.; Oshiro, C. M.; Taylor, E. W.; Kuntz, I. D.; Gibson, B. W.; Dollinger, G. High Throughput Protein Fold Identification by Using Experimental Constraints Derived from Intramolecular Cross-Links and Mass Spectrometry. Proc. Natl. Acad. Sci. U.S.A. 2000, 97(11), 5802-5806.

8. Schilling, B.; Row, R. H.; Gibson, B. W.; Guo, X.; Young, M. M. MS2Assign, Automated Assignment and Nomenclature of Tandem Mass Spectra of Chemically Crosslinked Peptides. J. Am. Soc. Mass Spectrom. 2003, 14(8), 834-850.

9. Back, J. W.; Sanz, M. A.; De Jong, L.; De Koning, L. J.; Nijtmans, L. G.; De Koster, C. G.; Grivell, L. A.; Van Der Spek, H.; Muijsers, A. O. A Structure for the Yeast Prohibitin Complex: Structure Prediction and Evidence from Chemical Crosslinking and Mass Spectrometry. Protein Sci. 2002, 11(10), 2471-2478.

10. Shih, C. L.; Chen, M. J.; Linse, K.; Wang, K. Molecular Contacts Between Nebulin and Actin: Cross-Linking of Nebulin Modules to the NTerminus of Actin. Biochemistry 1997, 36, 1814-1825.

11. Chen, T.; Jaffe, J. D.; Church, G. M. Algorithms for Identifying Protein Cross-Links Via Tandem Mass Spectrometry. J. Comput. Biol. 2001, 8 , 571-583.

12. Lacroix, M.; Rossi, V.; Gaboriaud, C.; Chevallier, S.; Jaquinod, M.; Thielens, N. M.; Gagnon, J.; Arlaud, G. J. Structure and Assembly of the Catalytic Region of Human Complement Protease C1r: A Three-Dimensional Model Based on Chemical Cross-Linking and Homology Modeling. Biochemistry 1997, 36(21), 6270-6282.

13. Taverner, T.; Hall, N. E.; O'Hair, R. A.; Simpson, R. J. Characterization of an Antagonist Interleukin-6 Dimer by Stable Isotope Labeling, Cross-linking, and Mass Spectrometry. J. Biol. Chem. 2002, 277(8), 46487-46492.

14. Rappsilber, J.; Siniossoglou, S.; Hurt, E. C.; Mann, M. A Generic Strategy to Analyze the Spatial Organization of Multi-Protein Complexes by Cross-Linking and Mass Spectrometry. Anal. Chem. 2000, 72(2), 267-275.

15. Chen, Z. A.; Jawhari, A.; Fischer, L.; Buchen, C.; Architecture of the RNA Polymerase II-TFIIF Complex Revealed by Cross-Linking and Mass Spectrometry. EMBO J. 2010, Jan. 21 [Epub ahead of print].

16. Chu, F.; Shan, S. O.; Moustakas, D. T.; Alber, F.; Egea, P. F.; Stroud R. M.; Walter, P.; Burlingame, A. L. Unraveling the Interface of Signal Recognition Particle and Its Receptor by Using Chemical Cross-Linking and Tandem Mass Spectrometry. Proc. Natl. Acad. Sci. U.S.A. 2004, 101(47), 16454-16459.

17. Chu, F.; Maynard, J. C.; Chiosis, G.; Nicchitta, C. V.; Burlingame, A. L. Identification of Novel Quaternary Domain Interactions in the Hsp90 Chaperone, GRP94. Protein Sci. 2006, 15(6), 1260-1269.

18. Schmitt-Ulms, G.; Legname, G.; Baldwin, M. A.; Ball, H. L.; Bradon, N.; Bosque, P. J.; Crossin, K. L.; Edelman, G. M.; DeArmond, S. J.; Cohen, E.;
Prusiner, S. B. Binding of Neural Cell Adhesion Molecules (N-Cams) to the Cellular Prion Protein. J. Mol. Biol. 2001, 314(5), 1209-1225.

19. Schmitt-Ulms, G.; Hansen, K.; Liu, J.; Cowdrey, C.; Yang, J.; DeArmond, S. J.; Cohen, F.E.; Prusiner, S.B.; Baldwin, M.A. Time-Controlled Transcardiac Perfusion Cross-Linking for the Study of Protein Interactions in Complex Tissues. Nat. Biotechnol. 2004, 22(6), 724-731.

20. Vasilescu, J.; Guo, X.; Kast, J. Identification of Protein-Protein Interactions Using In Vivo Cross-Linking and Mass Spectrometry. Proteomics 2004, 4, 3845-3854

21. Guerrero, C.; Tagwerker, C.; Kaiser, P.; Huang, L. An Integrated Mass Spectrometry-Based Proteomic Approach: Quantitative Analysis of Tandem Affinity-Purified In Vivo Cross-Linked Protein Complexes (QTAX) to Decipher the 26 S Proteasome-Interacting Network. Mol. Cell. Proteom. 2006, 5(2), 366-378.

22. Guerrero, C.; Milenkovic, T.; Przulj, N.; Kaiser, P.; Huang, L. Characterization of the Proteasome Interaction Network Using a QTAX-Based Tag-Tteam Strategy and Protein Interaction Network Analysis. Proc. Natl. Acad. Sci. U.S.A. 2008, 105(36), 13333-13338

23. Bousquet-Dubouch, M. P.; Baudelet, E.; Guerin, F.; Matondo, M. Uttenweiler-Joseph, S.; Burlet-Schiltz, O.; Monsarrat, B. Affinity Purification Strategy to Capture Human Endogenous Proteasome Complexes Diversity and to Identify Proteasome-Interacting Proteins. Mol. Cell. Proteom. 2009, 8(5), 1150-1164.

24. Tardiff, D. F.; Abruzzi, K. C.; Rosbash, M. Protein Characterization of Saccharomyces cerevisiae RNA Polymerase II After In Vivo CrossLinking. Proc. Natl. Acad. Sci. U.S.A. 2007, 104(50), 19948-19953.

25. Chowdhury, S. M.; Shi, L.; Yoon, H.; Ansong, C.; Rommereim, L. M. Norbeck, A. D.; Auberry, K. J.; Moore, R. J.; Adkins, J. N.; Heffron, F.; Smith, R. D. A Method for Investigating Protein-Protein Interactions Related to Salmonella Typhimurium Pathogenesis. J. Proteome Res. 2009, 8(3), 1504-1514.

26. Wallon, G.; Rappsilber, J.; Mann, M.; Serrano, L. Model for Stathmin/ OP18 Binding to Tubulin. EMBO J. 2000, 19(2), 213-222.

27. Trester-Zedlitz, M.; Kamada, K.; Burley, S. K.; Fenyo, D.; Chait, B. T.; Muir, T. W. A Modular Cross-Linking Approach for Exploring Protein Interactions. J. Am. Chem. Soc. 2003, 125(9), 2416-2425.

28. Tang, X.; Munske, G. R.; Siems, W. F.; Bruce, J. E. Mass Spectrometry Identifiable Cross-Linking Strategy for Studying Protein-Protein Interactions. Anal. Chem. 2005, 77(1), 311-318.

29. Zhang, H.; Tang, X.; Munske, G. R.; Tolic, N.; Anderson, G. A.; Bruce, J. E. Identification of Protein-Protein Interactions and Topologies in Living Cells with Chemical Cross-Linking and Mass Spectrometry. Mol. Cell. Proteom. 2009, 8(3), 409-420.

30. Chu, F.; Mahrus, S.; Craik, C. S.; Burlingame, A. L. Isotope-Coded and Affinity-Tagged Cross-Linking (ICATXL): An Efficient Strategy to Probe Protein Interaction Surfaces. J. Am. Chem. Soc. 2006, 128(32) 10362-10363.

31. Kang, S.; Mou, L.; Lanman, J.; Velu, S.; Brouillette, W. J.; Prevelige, P. E. Jr. Synthesis of Biotin-Tagged Chemical Cross-Linkers and Their Applications for Mass Spectrometry. Rapid Commun. Mass Spectrom. 2009, 23(11), 1719-1726.

32. Muller, D. R.; Schindler, P.; Towbin, H.; Wirth, U.; Voshol, H.; Hoving, S.; Steinmetz, M. O. Isotope-Tagged Cross-Linking Reagents, a New Tool in Mass Spectrometric Protein Interaction Analysis. Anal. Chem. 2001, 73, 1927-1934.

33. Collins, C. J.; Schilling, B.; Young, M.; Dollinger, G.; Guy, R. K. Isotopically Labeled Cross-Linking Reagents: Resolution of Mass Degeneracy in the Identification of Cross-Linked Peptides. Bioorg. Med. Chem. Lett. 2003, 13(22), 4023-4026.

34. Petrotchenko, E. V.; Olkhovik, V. K.; Borchers, C. H. Isotopically Coded Cleavable Cross-Linker for Studying Protein-Protein Interaction and Protein Complexes. Mol. Cell. Proteom. 2005, 4(8), 1167-1179.

35. Sinz, A.; Wang, K. Mapping Protein Interfaces with a Fluorogenic Cross-Linker and Mass Spectrometry: Application to NebulinCalmodulin Complexes. Biochemistry 2001, 40, 7903-7913.

36. Sinz, A.; Wang, K. Mapping Spatial Proximities of Sulfhydryl Groups in Proteins Using a Fluorogenic Cross-Linker and Mass Spectrometry. Anal. Biochem. 2004, 331, 27-32.

37. Back, J. W.; Hartog, A. F.; Dekker, H. L.; Muijsers, A. O.; de Koning, L. J. de Jong, L. A New Cross-Linker for Mass Spectrometric Analysis of the Quaternary Structure of Protein Complexes. J. Am. Soc. Mass Spectrom. 2001, 12, 222-227.

38. Zhang, H.; Tang, X.; Munske, G. R.; Zakharova, N.; Yang, L.; Zheng, C.; Wolff, M. A.; Tolic, N.; Anderson, G. A.; Shi, L.; Marshall, M. J. Fredrickson, J. K.; Bruce, J. E. In Vivo Identification of the Outer Membrane Protein Omca-Mtrc Interaction Network in Shewanella Oneidensis Mr-1 Cells Using Novel Hydrophobic Chemical CrossLinkers. J. Proteome Res. 2008, 7(4), 1712-1720.

39. Chowdhury, S. M.; Du, X.; Tolic, N.; Wu, S.; Moore, R. J.; Mayer, M. U.; Smith, R. D.; Adkins, J. N. Identification of Cross-Linked Peptides after Click-Based Enrichment Using Sequential Collision-Induced Dissociation and Electron Transfer Dissociation Tandem Mass Spectrometry. Anal. Chem. 2009, 81(13), 5524-5532.

40. Kasper, P. T.; Back, J. W.; Vitale, M.; Hartog, A. F.; Roseboom, W.; de Koning, L. J.; van Maarseveen, J. H.; Muijsers, A. O.; de Koster, C. G.; de Jong, L. An Aptly Positioned Azido Group in the Spacer of a Protein Cross-Linker for Facile Mapping of Lysines in Close Proximity. Chem. Biochem. 2007, 8(11), 1281-1292.

41. Nessen, M. A.; Kramer, G.; Back, J.; Baskin, J. M.; Smeenk, L. E.; de Koning, L. J.; van Maarseveen, J. H.; de Jong, L.; Bertozzi, C. R. 
Hiemstra, H.; de Koster, C. G. Selective Enrichment of Azide-Containing Peptides from Complex Mixtures. J. Proteome Res. 2009, 8(7), 3702-3711.

42. Rostovtsev, V. V.; Green, L. G.; Fokin, V. V.; Sharpless, K. B. A Stepwise Huisgen Cycloaddition Process: Copper(I)-Catalyzed Regioselective "Ligation" of Azides and Terminal Alkynes. Angew. Chem. Int. Ed. Engl. 2002, 41(14), 2596-2599.

43. Salisbury, C. M.; Cravatt, B. F. Activity-Based Probes for Proteomic Profiling of Histone Deacetylase Complexes. Proc. Natl. Acad. Sci. U.S.A. 2007, 104(4), 1171-1176.

44. Sieber, S. A.; Cravatt, B. F. Analytical Platforms for Activity-Based Protein Profiling-Exploiting the Versatility of Chemistry for Functional Proteomics. Chem. Commun. (Camb) 2006, 22, 2311-2319.

45. Speers, A. E.; Cravatt, B. F. Profiling Enzyme Activities In Vivo Using Click Chemistry Methods. Chem. Biol. 2004, 11(4), 535-546.

46. Speers, A. E.; Cravatt, B. F. A Tandem Orthogonal Proteolysis Strategy for High-Content Chemical Proteomics. J. Am. Chem. Soc. 2005, 127(28), 10018-10019.

47. Gubbens, J.; Ruijter, E.; de Fays, L. E.; Damen, J. M.; de Kruijff, B.; Slijper, M.; Rijkers, D. T.; Liskamp, R. M.; de Kroon, A. I. Photocrosslinking and Click Chemistry Enable the Specific Detection of Proteins Interacting with Phospholipids at the Membrane Interface. Chem. Biol. 2009, 16(1), 3-14.

48. Speers, A. E.; Adam, G. C.; Cravatt, B. F. Activity-Based Protein Profiling In Vivo Using a Copper(i)-Catalyzed Azide-Alkyne [3 + 2] Cycloaddition. J. Am. Chem. Soc. 2003, 125(16), 4686-4687.

49. Agard, N. J.; Prescher, J. A.; Bertozzi, C. R. A Strain-Promoted [3 + 2] Azide-Alkyne Cycloaddition for Covalent Modification of Biomolecules in Living Systems. J. Am. Chem. Soc. 2004, 126(46), 15046-15047.

50. Breinbauer, R.; Kohn, M. Azide-Alkyne Coupling: A Powerful Reaction for Bioconjugate Chemistry. Chem. Biochem. 2003, 4(11), 1147-1149.

51. Agard, N. J.; Baskin, J. M.; Prescher, J. A.; Lo, A.; Bertozzi, C. R. A Comparative Study of Bioorthogonal Reactions with Azides. ACS Chem. Biol. 2006, 1(10), 644-648.

52. Baskin, J. M.; Prescher, J. A.; Laughlin, S. T.; Agard, N. J.; Chang, P. V.; Miller, I. A.; Lo, A.; Codelli, J. A.; Bertozzi, C. R. Copper-Free Click Chemistry for Dynamic in Vivo Imaging. Proc. Natl. Acad. Sci. U.S.A. 2007, 104(43), 16793-16797.

53. Saxon, E.; Armstrong, J. I.; Bertozzi, C. R. A “Traceless" Staudinger Ligation for the Chemoselective Synthesis of Amide Bonds. Org. Lett. 2000, 2(14), 2141-2143.

54. Saxon, E.; Bertozzi, C. R. Cell Surface Engineering by a Modified Staudinger Reaction. Science 2000, 287(5460), 2007-2010.

55. Kohn, M.; Breinbauer, R. The Staudinger Ligation-a Gift to Chemical Biology. Angew. Chem. Int. Ed. Engl. 2004, 43(24), 3106-3116.

56. Sprung, R.; Nandi, A.; Chen, Y.; Kim, S. C.; Barma, D.; Falck, J. R.; Zhao, Y. Tagging-Via-Substrate Strategy for Probing O-Glcnac Modified Proteins. J. Proteome Res. 2005, 4(3), 950-957.

57. Kiick, K. L.; Saxon, E.; Tirrell, D. A.; Bertozzi, C. R. Incorporation of Azides into Recombinant Proteins for Chemoselective Modification by the Staudinger Ligation. Proc. Natl. Acad. Sci. U.S.A. 2002, 99(1), 19-24.
58. Luchansky, S. J.; Argade, S.; Hayes, B. K.; Bertozzi, C. R. Metabolic Functionalization of Recombinant Glycoproteins. Biochemistry 2004 43(38), 12358-12366.

59. Vila, A.; Tallman, K. A.; Jacobs, A. T.; Liebler, D. C.; Porter, N. A. Marnett, L. J. Identification of Protein Targets of 4-Hydroxynonenal Using Click Chemistry for Ex Vivo Biotinylation of Azido and Alkynyl Derivatives. Chem. Res. Toxicol. 2008, 21(2), 432-444.

60. Reddie, K. G.; Seo, Y. H.; Muse Iii, W. B.; Leonard, S. E.; Carroll, K. S. A Chemical Approach for Detecting Sulfenic Acid-Modified Proteins in Living Cells. Mol. Biosyst. 2008, 4(6), 521-531.

61. Kostiuk, M. A.; Keller, B. O.; Berthiaume, L. G. Nonradioactive Detection of Palmitoylated Mitochondrial Proteins Using an Azido-Palmitate Analogue. Methods Enzymol. 2009, 457, 149-165.

62. Chu, F.; Baker, P. R.; Burlingame, A. L.; Chalkley, R. J. Finding Chimeras: A Bioinformatic Strategy for Identification of Cross-Linked Peptides. Mol. Cell. Proteom. 2009, 9(1), 25-31.

63. van der Veken, P.; Dirksen, E. H.; Ruijter, E.; Elgersma, R. C.; Heck, A. J.; Rijkers, D. T.; Slijper, M.; Liskamp, R. M. Development of a Novel Chemical Probe for the Selective Enrichment of Phosphorylated Serineand Threonine-Containing Peptides. Chem. Biochem. 2005, 6(12), $2271-$ 2280.

64. Chan, T. R.; Hilgraf, R.; Sharpless, K. B.; Fokin, V. V. Polytriazoles as Copper(I)-Stabilizing Ligands in Catalysis. Org. Lett. 2004, 6(17), 28532855.

65. Pearson, K. M.; Pannell, L. K.; Fales, H. M. Intramolecular CrossLinking Experiments on Cytochrome $\mathrm{c}$ and Ribonuclease A Using an Isotope Multiplet Method. Rapid Commun. Mass Spectrom. 2002, 16(3), 149-159.

66. Dihazi, G. H.; Sinz, A. Mapping Low-Resolution Three-Dimensional Protein Structures Using Chemical Cross-Linking and Fourier Transform Ion-Cyclotron Resonance Mass Spectrometry. Rapid Commun. Mass Spectrom. 2003, 17(17), 2005-2014.

67. Lee, Y. J.; Lackner, L. L.; Nunnari, J. M.; Phinney, B. S. Shotgun Cross-Linking Analysis for Studying Quaternary and Tertiary Protein Structures. J. Proteome Res. 2007, 6(10), 3908-3917.

68. Guo, X.; Bandyopadhyay, P.; Schilling, B.; Young, M. M.; Fujii, N.; Aynechi, T.; Guy, R. K.; Kuntz, I. D.; Gibson, B. W. Partial Acetylation of Lysine Residues Improves Intraprotein Cross-Linking. Anal. Chem. 2008, 80(4), 951-960.

69. Mirkin, N.; Jaconcic, J.; Stojanoff, V.; Moreno, A. High Resolution X-Ray Crystallographic Structure of Bovine Heart Cytochrome c and Its Application to the Design of an Electron Transfer Biosensor. Proteins 2008, 70(1), 83-92.

70. Kruppa, G. H.; Schoeniger, J.; Young, M. M. A Top Down Approach to Protein Structural Studies Using Chemical Cross-Linking and Fourier Transform Mass Spectrometry. Rapid Commun. Mass Spectrom. 2003, 17(2), 155-162. 